\title{
Article \\ Cellulose-Based Hectocycle Nanopolymers: Synthesis, Molecular Docking and Adsorption of Difenoconazole from Aqueous Medium
}

\author{
Bayan Khalaf ${ }^{1} \mathbb{D}$, Othman Hamed ${ }^{1, *}$, Shehdeh Jodeh ${ }^{1, *}$, Roland Bol ${ }^{2} \mathbb{D}$, Ghadir Hanbali ${ }^{1} \mathbb{D}$, Zaki Safi $^{3}$, \\ Omar Dagdag ${ }^{4}\left(\mathbb{D}\right.$, Avni Berisha ${ }^{5,6}$ (D) and Subhi Samhan ${ }^{7}$
}

check for

updates

Citation: Khalaf, B.; Hamed, O.; Jodeh, S.; Bol, R.; Hanbali, G.; Safi, Z.; Dagdag, O.; Berisha, A.; Samhan, S. Cellulose-Based Hectocycle Nanopolymers: Synthesis, Molecular Docking and Adsorption of Difenoconazole from Aqueous Medium. Int. J. Mol. Sci. 2021, 22 , 6090. https://doi.org/10.3390/ ijms22116090

Academic Editor: Carlo Crescenz

Received: 9 May 2021

Accepted: 27 May 2021

Published: 4 June 2021

Publisher's Note: MDPI stays neutral with regard to jurisdictional claims in published maps and institutional affiliations.

Copyright: (C) 2021 by the authors Licensee MDPI, Basel, Switzerland This article is an open access article distributed under the terms and conditions of the Creative Commons Attribution (CC BY) license (https:// creativecommons.org/licenses/by/ $4.0 /)$
1 Chemistry Department, Faculty of Science, An-Najah National University, Nablus P.O. Box 7, Palestine; bayan.kh107@hotmail.com (B.K.); g.hanbali@najah.edu (G.H.)

2 Institute of Bio and Geosciences, Agrosphere (IBG-3), Forschungszentrum Jülich GmbH, 52425 Jülich, Germany; r.bol@fz-juelich.de

3 Chemistry Department, Faculty of Science, Al Azhar University-Gaza, Gaza P.O. Box 1277, Palestine; zaki.safi@gmail.com

4 Laboratory of Industrial Technologies and Services (LITS), Department of Process Engineering, Height School of Technology, Sidi Mohammed Ben Abdallah University, P.O. Box 2427, Fez 30000, Morocco; omar.dagdag@uit.ac.ma

5 Department of Chemistry, Faculty of Natural and Mathematics Science, University of Prishtina, 10000 Prishtina, Kosovo; avni.berisha@uni-pr.edu

6 Materials Science-Nanochemistry Research Group, NanoAlb-Unit of Albanian Nanoscience and Nanotechnology, 1000 Tirana, Albania

7 Research and Development Center, Palestine Water Authority (PWA), Ramallah P.O. Box 2174, Palestine; subhisamhan@yahoo.com

* Correspondence: ohamed@najah.edu (O.H.); sjodeh@najah.edu (S.J.); Tel.: +970-594-466-271 (O.H. \& S.J.)

\begin{abstract}
The goal of this work was to develop polymer-based heterocycle for water purification from toxic pesticides such as difenoconazole. The polymer chosen for this purpose was cellulose nanocrystalline (CNC); two cellulose based heterocycles were prepared by crosslinking with 2,6pyridine dicarbonyl dichloride (Cell-X), and derivatizing with 2-furan carbonyl chloride (Cell-D). The synthesized cellulose-based heterocycles were characterized by SEM, proton NMR, TGA and FT-IR spectroscopy. To optimize adsorption conditions, the effect of various variable such as time, adsorbent dose, $\mathrm{pH}$, temperature, and difenoconazole initial concentration were evaluated. Results showed that, the maximum difenoconazole removal percentage was about $94.7 \%$, and $96.6 \%$ for Cell$X$ and Cell-D, respectively. Kinetic and thermodynamic studies on the adsorption process showed that the adsorption of difenoconazole by the two polymers is a pseudo-second order and follows the Langmuir isotherm model. The obtained values of $\Delta \mathrm{G}^{\circ}$ and $\Delta \mathrm{H}$ suggest that the adsorption process is spontaneous at room temperature. The results showed that Cell- $X$ could be a promising adsorbent on a commercial scale for difenoconazole. The several adsorption sites present in Cell-X in addition to the semi crown ether structure explains the high efficiency it has for difenoconazole, and could be used for other toxic pesticides. Monte Carlo (MC) and Molecular Dynamic (MD) simulation were performed on a model of Cell-X and difenoconazole, and the results showed strong interaction.
\end{abstract}

Keywords: water treatment; persistent pesticides; difenoconazole; cellulose nanocrystalline; 2,6-pyridine-dicarbonyl dichloride; 2-furan carbonyl chloride

\section{Introduction}

The global concern about pollution caused by persistent pesticides emerges from their ability to bio-accumulate and bio-magnify in the environment, as well as causing many adverse effects for mankind [1-3]. The techniques reported in the literature for adsorption of pesticides from water include UV photolysis, electrochemical degradation, adsorption, fenton oxidation, ultrasonication, membrane technology, photo catalyst, and 
others. Among these treatment techniques, adsorption showed obvious advantages such as reusability, lower cost and ease of operation [3-12]. Removing of difenoconazole by remediation was also investigated in previous studies. Several adsorbents for difenoconazole extraction from water were also suggested, such as cyclodextrin-based adsorbents, mesoporous activated carbon and graphene-based compounds [13-17].

Difenoconazole has a solubility in water of $(15 \mathrm{mg} / \mathrm{L})$ at room temperature. It is a very persistent pesticide with half-life in soil of more than seven months. This synthetic fungicide is used to prevent fungal diseases in plants owing to its systemic and broad-spectrum antifungal activities, for instance, basidiomycetes, ascomycetes and deuteromycetes. It is also an ergosterol biosynthesis inhibitor which is used during the entire growing season of crops $[1,18]$. Difenoconazole is considered an inhibitor of aromatase activity in human adrenocortical carcinoma cell line H295R. Due to its different molecular configurations, enantiomers of this pesticide probably exhibit stereoselectivity in the process of distribution, toxicity, absorption and degradation in the environment. Previous studies on the fungicidal activity of difenoconazole implied that the biological activities of difenoconazole had enantioselectivity with the $(2 \mathrm{R}, 4 \mathrm{~S})$-difenoconazole, with a more pronounced fungicidal activity than other forms $[18,19]$.

Comparing difenoconazole with other triazole fungicides, it possesses relatively high acute toxicity, so the contamination of aquatic ecosystems by difenoconazole is of great environmental concern. In addition, exposure to water polluted by the pesticide difenoconazole has hazardous effects on human health that may cause death in the case of high concentrations [1,18-20].

One of the most abundant biological and renewable materials worldwide is cellulose, which can be used as an industrial feedstock for many derivatives and in an unlimited number of applications. Additionally, cellulose with modified surface is considered of great interest as it has many commercial applications [21-29]. This study aims to purify water from difenoconazole persistent pesticide using cellulose nanocrystalline cross-linked with 2,6-pyridine dicarbonyl dichloride (Cell-X) and cellulose derivatized with the heterocyclic compound 2 -furan carbonyl chloride (Cell-D). The effects of variables such as adsorbent dose, $\mathrm{pH}$, temperature, pesticide concentration and time were studied. In addition, isotherms, adsorption kinetics and thermodynamics for adsorption using both polymer Cell-X and Cell-D were investigated.

\section{Results and Discussion}

\subsection{Polymer Analysis}

Cellulose crosslinking with 2,6-pyridine di-carbonyl dichloride and acylation of cellulose carried in DMAc/ $\mathrm{LiCl}$ solvent mixture are shown in Figure 1. These chemical reagents were chosen because of their functional groups in which the presence of the aromatic heterocyclic and the carbonyl and chloride groups make them perfect adsorbents for difenoconazole removal from water, such that these functional groups bind difenoconazole pesticide through various physical interactions including dipole-dipole interaction, H-bonding and $\pi-\pi$ stacking [30]. 


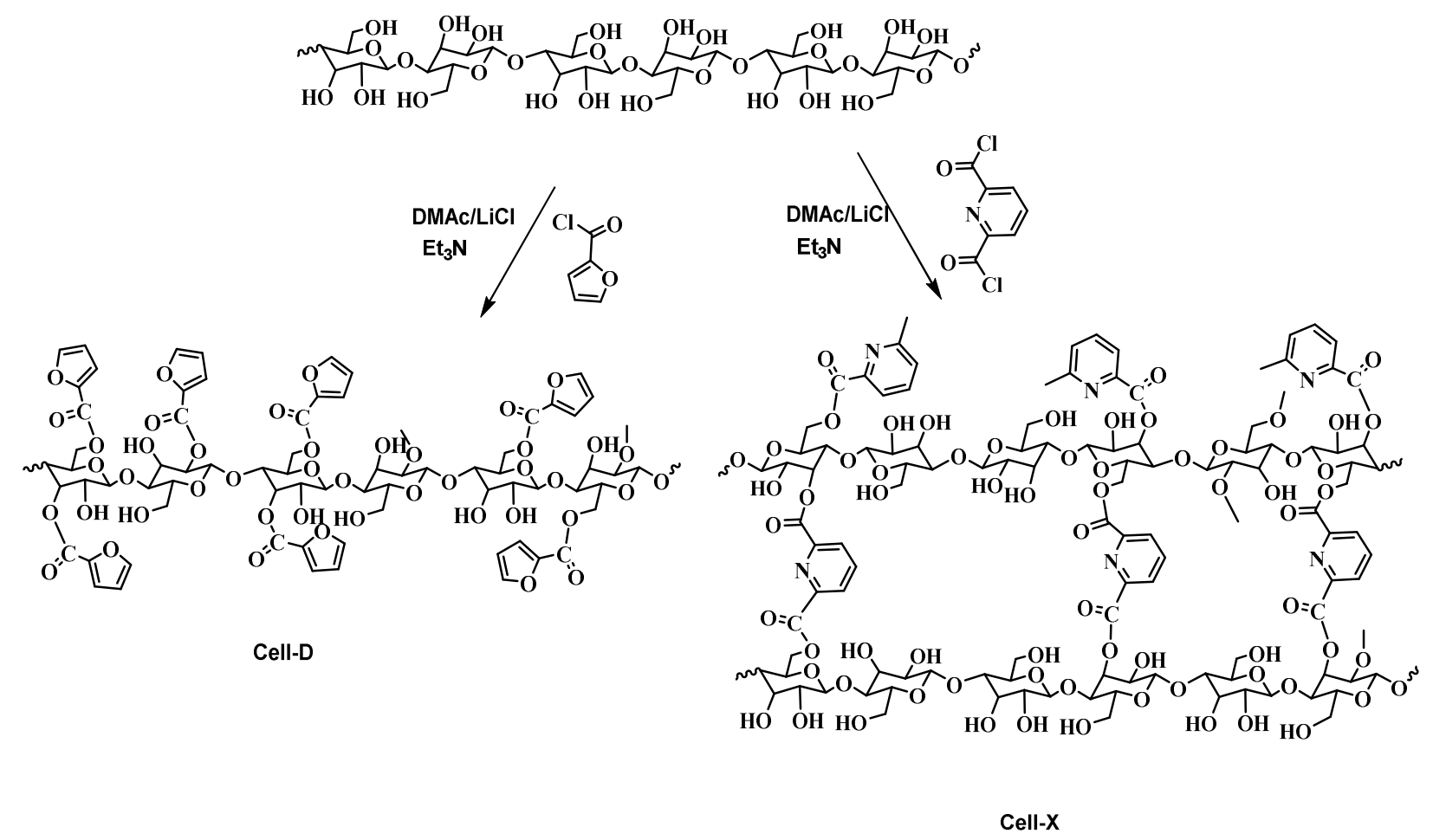

Figure 1. Preparation of Cell-D and Cell-X.

\subsubsection{FT-IR Analysis}

The target cellulosic polymers Cell-X and Cell-D were characterized by FT-IR analysis, and the spectrum obtained for Cell-D is shown in Figure S1. The C=C of the furan ring showed a small band at $1576 \mathrm{~cm}^{-1}$. The peak at $1179.74 \mathrm{~cm}^{-1}$ corresponds to C-O-C of cellulose ( $\beta$-glycosidic linkage). The peak at $1717.61 \mathrm{~cm}^{-1}$ corresponds to the ester carbonyl, and the low frequency of the carbonyl groups could be related to conjugation with the furan ring. The FT-IR of Cell-X shows almost similar bands except for the disappearance of the ester band and the appearance of the amide band that showed up at $1650 \mathrm{~cm}^{-1}$. The similarities between FT-IR spectra for both Cell-X and Cell-D polymers could be due to both having the same polymer back bones and functionalities.

\subsubsection{H NMR Spectroscopy}

The prepared nano-polymer Cell-D was characterized by ${ }^{1} \mathrm{H}$ NMR. The spectrum of Cell-D is shown in Figure S2, and DMSO- $\mathrm{d}_{6}$ was used as solvent. ${ }^{1} \mathrm{H}$ NMR analysis shows three peaks between $6.71-8.12 \mathrm{ppm}$, attributed to aromatic furan protons, whereas the cellulose peaks appear between $2.7-5.0 \mathrm{ppm}$. The four peaks between $\delta 3.1$ and 3.60 are from the four $\mathrm{C} 2, \mathrm{C} 3, \mathrm{C} 4$ and $\mathrm{C} 5$ protons, and the peak at $\delta 3.1$ is consistent with the chemical shift of $\mathrm{H}_{2}$. The spectrum also detects downfield peaks at $\delta 4.35$ which contributed to the proton $\mathrm{H}^{1}$ at the anomeric carbon. The two multiple peaks at $\delta 3.92$ and 3.85 are assigned to the $2 \mathrm{H}^{\prime} \mathrm{s}$ at $\mathrm{C}-6$. These results are consistent with those previously reported [31,32].

We were not able to obtain proton NMR for crosslinked cellulose Cell-X because of a solubility issue which could be contributed to by the crosslinking.

\subsubsection{SEM Analysis}

SEM images of Cell-D and Cell- $X$ were obtained at three magnifications $(1,10$, and $100 \mu \mathrm{m})$, shown in Figures 2 and 3. 

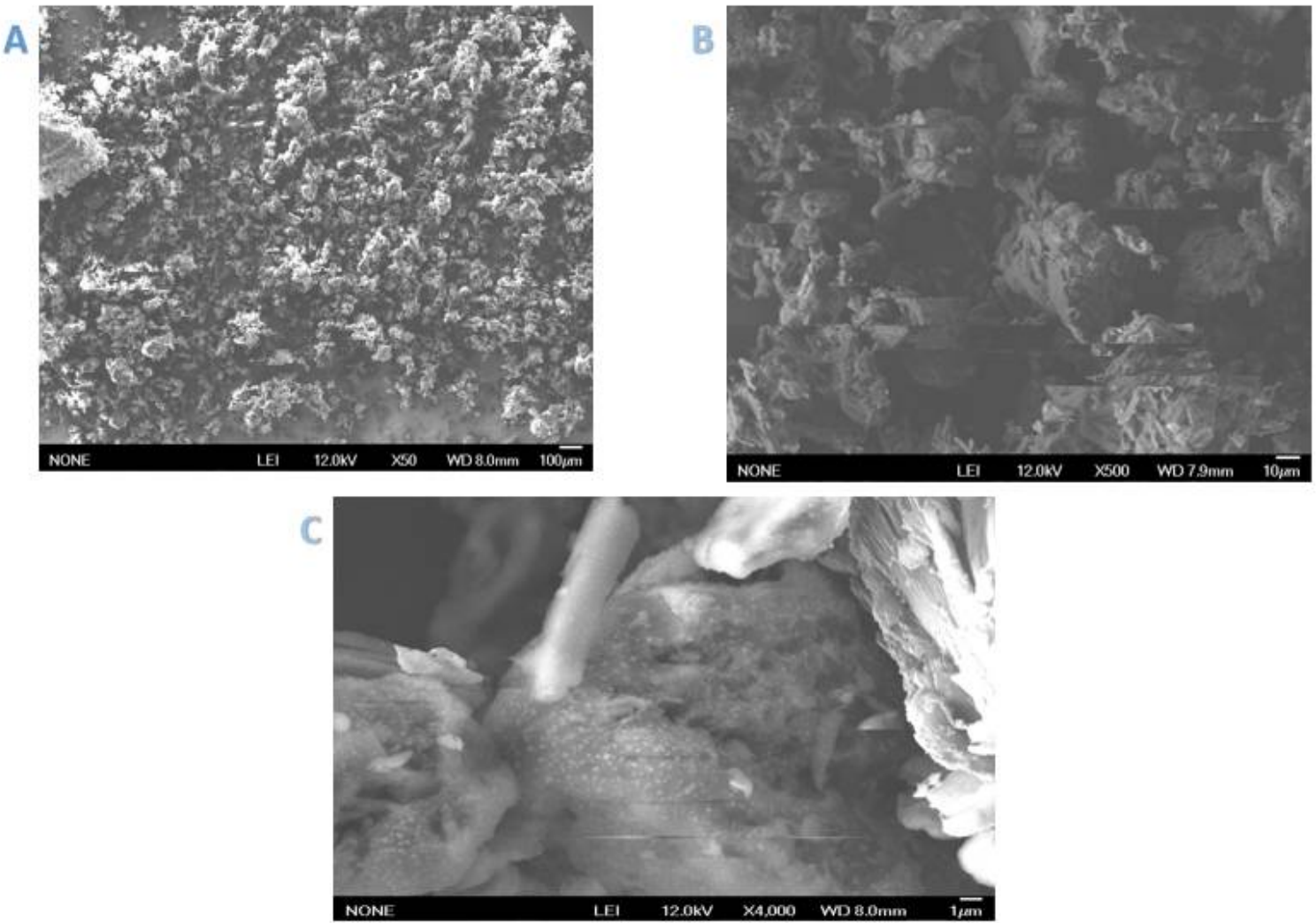

Figure 2. SEM analysis of Cell-X at three different magnifications: (A): 100, (B): 10, \& (C): $1 \mu \mathrm{m}$.
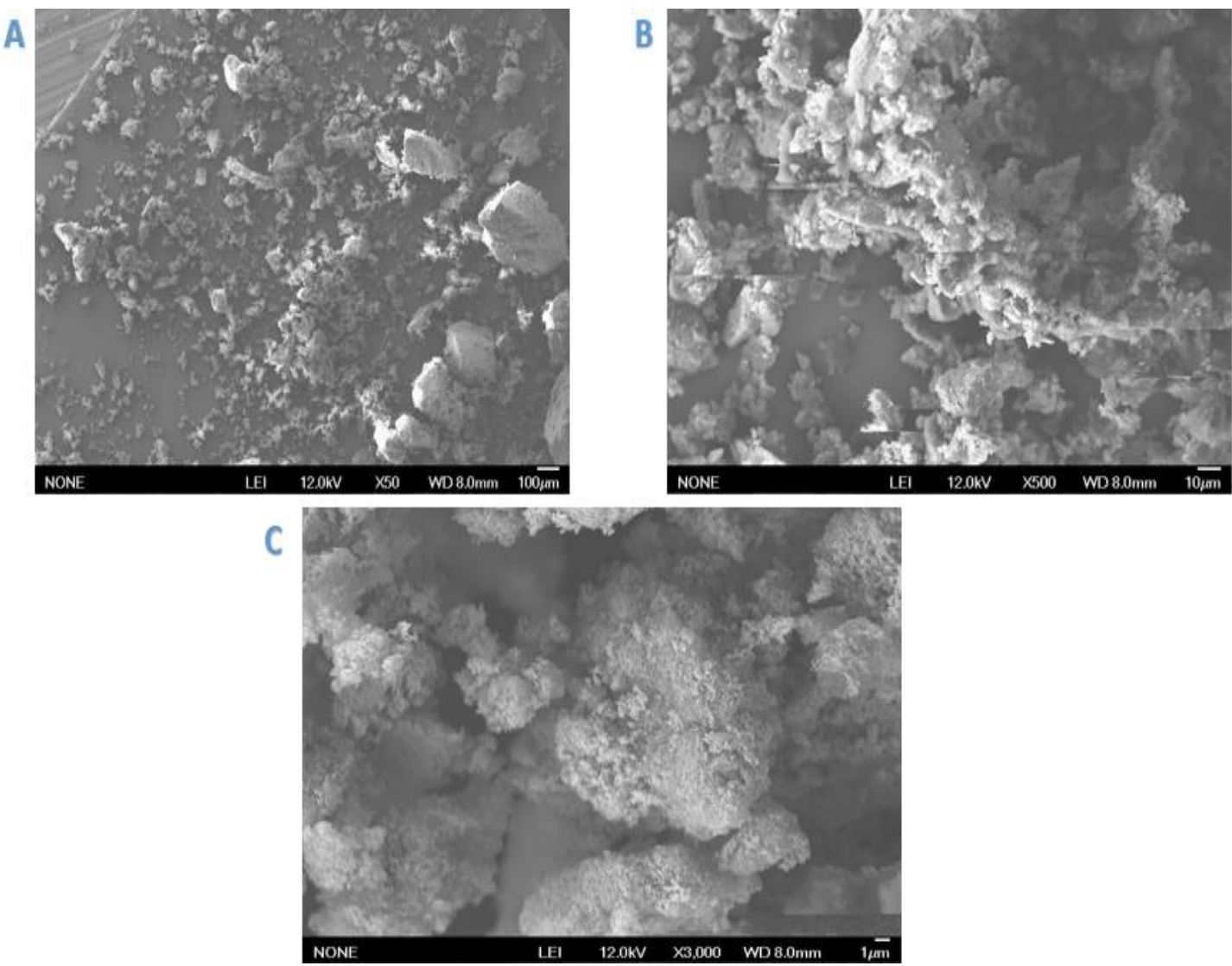

Figure 3. SEM analysis of Cell-D at three different magnifications: (A): 100, (B): 10, \& (C): $1 \mu \mathrm{m}$. 
The obtained SEM images of Cell-X show a porous structure, with high surface. These characteristics contribute to the high adsorbent efficiency of the polymer. In addition, SEM analysis of Cell-D (Figure 3), shows almost similar morphology to that detected for Cell-X.

\subsubsection{TGA Analysis}

Thermogravimetric analysis was carried out to study the thermal stability of Cell-X and Cell-D. Figure S3A,B show the single step weight loss behavior of both polymers. The degradation temperature of both polymers was observed at around $250{ }^{\circ} \mathrm{C}$. A notable difference between the TGA analysis of the two polymers is that the weight loss from Cell-X was lower at $250{ }^{\circ} \mathrm{C}$, which could be related to cross-linking that adds stability to the polymer.

\subsection{Adsorption}

The effect of variables on adoption efficiency of Cell-X and Cell-D are listed below. The effect of each variable was evaluated while marinating the other variables at optimum-values.

\subsubsection{Adsorption Time}

The adsorption of difenoconazole from water Cell-X or Cell-D was carried out as a function of time. The other variables such as temperature, $\mathrm{pH}$, adsorbent dose and initial concentration were kept constant at $\left(20^{\circ} \mathrm{C}, \mathrm{pH} 7,10.0 \mathrm{mg}\right.$ as adsorbent dose and $10.0 \mathrm{ppm}$ as difenoconazole concentration). The results are summarized in Figure 4; as shown, the adsorption started rapidly then leveled off at about $22 \mathrm{~min}$ for both polymers Cell-X and Cell-B. During the initial time, the binding sites are available and become occupied as time progresses. The percentage of removal of difenoconazole reached about $87 \%$ and $86 \%$ for Cell-D and Cell-X, respectively. Acylation of cellulose Cell-D and crosslinked cellulose Cell- $X$ make them unique adsorbents as they are able to trap difenoconazole pesticide through various intermolecular forces including $\pi-\pi$ interaction, dipole-dipole and H-bonding.

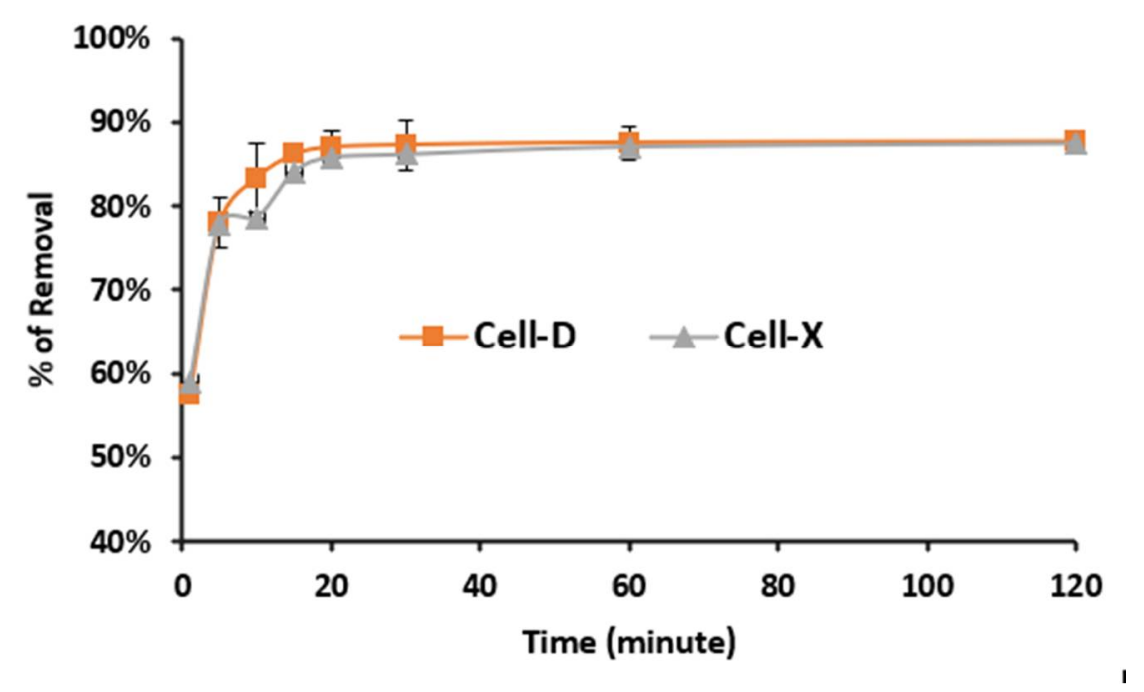

Figure 4. Effect of time on adsorption efficiency of Cell-X and Cell-D ( $\mathrm{C}_{\mathrm{o}}: 10 \mathrm{ppm}$, dosage: $10 \mathrm{mg}$, temperature: $20^{\circ} \mathrm{C}$, volume: $\left.10 \mathrm{~mL}, \mathrm{pH}: 7\right)$.

\subsection{2. $\mathrm{pH}$ Value}

The solution $\mathrm{pH}$ is a critical factor in adsorption, since by varying the $\mathrm{pH}$ value, the polymer and the adsorbate surface charge will be controlled by the $\mathrm{pH}$ effect. In this study the removal efficiency increased along with the $\mathrm{pH}$ values as shown in Figure 5, then started to drop at a $\mathrm{pH}$ value higher than 8.0. At low $\mathrm{pH}$ value, the difenoconazole $\mathrm{N}$ are in ammonium form $\left(-\mathrm{NR}_{3} \mathrm{H}^{+}\right)$, so the adsorption efficiency was the lowest. As the $\mathrm{pH}$ reached 6.0, the Ns started to deprotonate and the adsorption efficiency reached the highest 
$\mathrm{pH}$ value of 6.5 for Cell-X and 7.5 for Cell-D. This could be attributed to the availability of a lone pair of electrons on the $\mathrm{N}$, binding strongly with the polymer binding sites. This highest removal was about $88.1 \%$ and $88.7 \%$ for Cell-X and Cell-D, respectively.

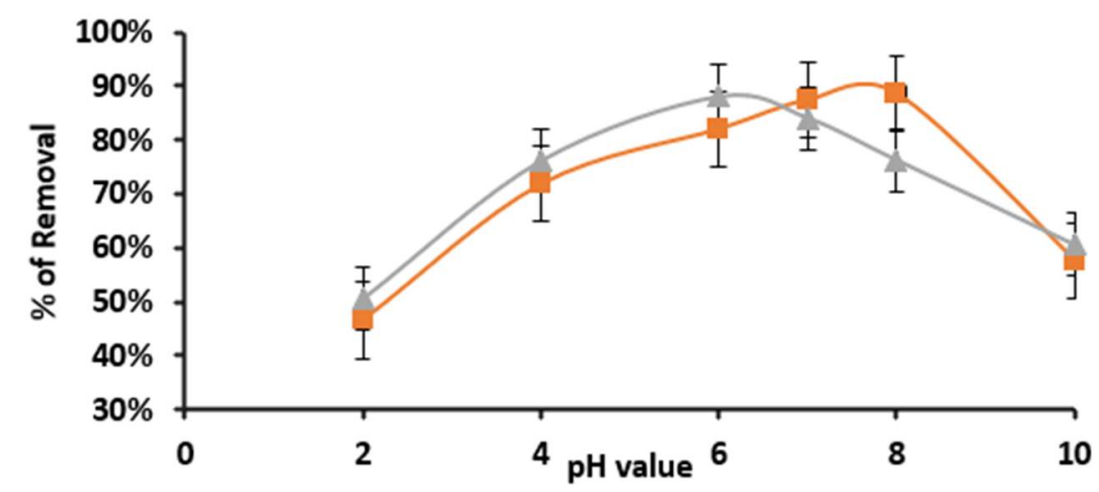

Figure 5. Effect of $\mathrm{pH}$ value on adsorption efficiency of Cell- $X$ and Cell-D ( $\mathrm{C}_{\mathrm{I}}: 10 \mathrm{ppm}$, dosage: $10 \mathrm{mg}$, volume: $10 \mathrm{~mL}$, temperature: $20^{\circ} \mathrm{C}$, time: $20 \mathrm{~min}$ of Cell-D, time: $60 \mathrm{~min}$ of Cell-X).

\subsubsection{Initial Concentration of Difenoconazole}

The initial concentration's effect on adsorption efficiency was also evaluated, while the other variables $\left(\mathrm{T}, \mathrm{t}, \mathrm{pH}\right.$, and adsorbent dose) were kept constant at $20^{\circ} \mathrm{C}, 10 \mathrm{mg}$ as adsorbent dose, adsorption time: $20 \mathrm{~min}$ and $60 \mathrm{~min}$ for Cell-D and Cell-X, respectively, $\mathrm{pH} 8$ and 6 for Cell-D and Cell-X, respectively. The highest percentage removal of difenoconazole at an initial concentration of $10.0 \mathrm{ppm}$ was $88.2 \%$ using Cell-D and $92.0 \%$ using Cell-X (Figure 6).

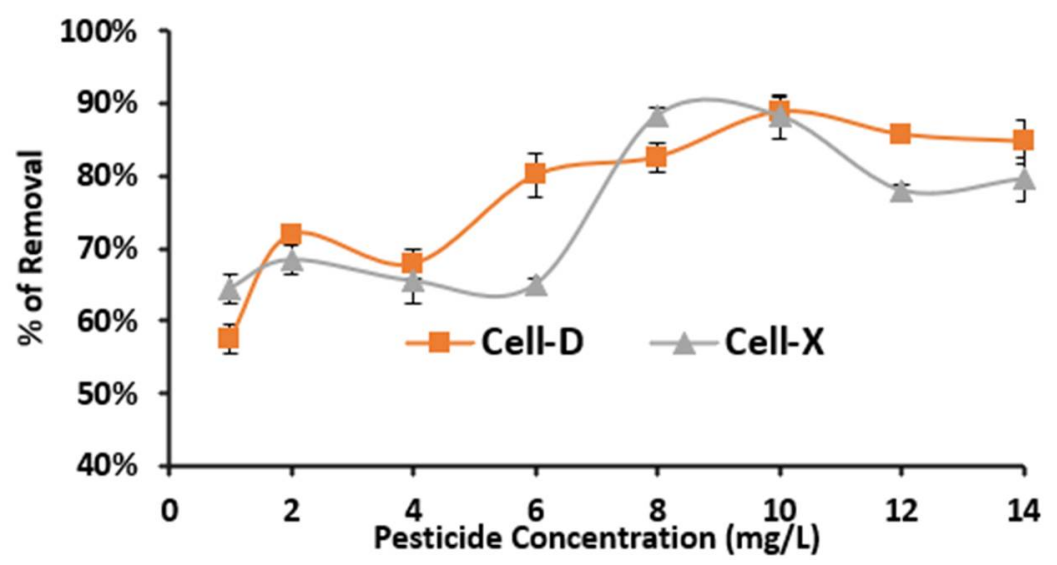

Figure 6. Effect of difenoconazole initial concentration on adsorption efficiency of Cell-X and Cell-D (temperature: $20^{\circ} \mathrm{C}$, dosage: $10 \mathrm{mg}$, volume: $10 \mathrm{~mL}$ ).

At low concentration of difenoconazole, the driving force for adsorption was the adsorbate concentration [33], so as the initial concertation increases, the adsorption increases. Then, the limiting factor for adsorption becomes the availability of the active binding sites, controlled by the adsorbent dose. According to the results shown in Figure 6, at $10.0 \mathrm{ppm}$ the binding sites are saturated, and at concentration higher than $10.0 \mathrm{ppm}$ the efficiency tends to drop.

\subsubsection{Temperature}

The temperature effect on percentage removal of difenoconazole by Cell- $\mathrm{X}$ and Cell$\mathrm{D}$ was also evaluated. As above, the other variables were kept constant at optimum conditions (for Cell-D: $\mathrm{pH}$ 8, $20 \mathrm{~min}, 10 \mathrm{ppm}$ difenoconazole concentration and $10 \mathrm{mg}$ as adsorbent dose) and (for Cell-X: pH 6, $60 \mathrm{~min}, 8 \mathrm{ppm}$ difenoconazole concentration and 
$10 \mathrm{mg}$ dose). The results are summarized in Figure 7. The maximum adsorption efficiency was determined to be at room temperature; as the temperature increased, the percentage for removal started to decrease. The results indicate a spontaneous exothermic adsorption.

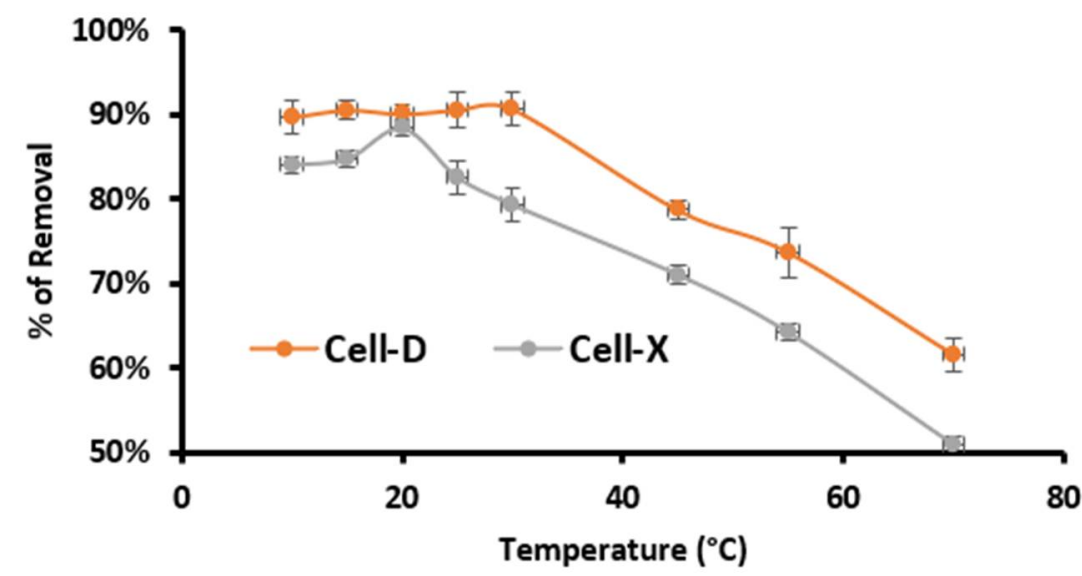

Figure 7. Effect of temperature on adsorption efficiency of Cell-X and Cell-D. (Dosage: $10 \mathrm{mg}$, volume: $10 \mathrm{~mL}$, pH: 6 and 8 for Cell-X and Cell-D, respectively).

\subsubsection{Adsorbent Dose}

The dosage that provided the highest adsorption efficiency for difenoconazole was determined in this part of the study. This was accomplished by conducting the experiment on a $10 \mathrm{~mL}$ solution of each difenoconazole at a concentration of 10.0 and $8.0 \mathrm{ppm}$ for Cell-D and Cell-X, respectively, a pH value of 8 for Cell-D and $\mathrm{pH}$ of 6 for Cell-X, and contact time of $20 \mathrm{~min}$ for Cell-D and $60 \mathrm{~min}$ for Cell-X, at room temperature. The effect of the adsorbent dosage on the removal of difenoconazole is presented in Figure 8. As shown, the percentage removal of difenoconazole increased along with increase in the Cell- $X$ and Cell-D dosage. The percentage removal reached about $96.5 \%$ and $94.2 \%$ for Cell- $X$ and Cell-D, respectively. This could be attributed to the type of adsorption mechanisms, which can be described as diffusion and physical interaction. As the dosage increases, the number of binding sites available for interaction increases, and so does the removal efficiency. When all coordination sites on the adsorbent surface are occupied, the diffusion process begins, and in this case could be controlled by an osmosis-like process, the adsorption efficiency leveling off as the equilibrium state is attained [34].

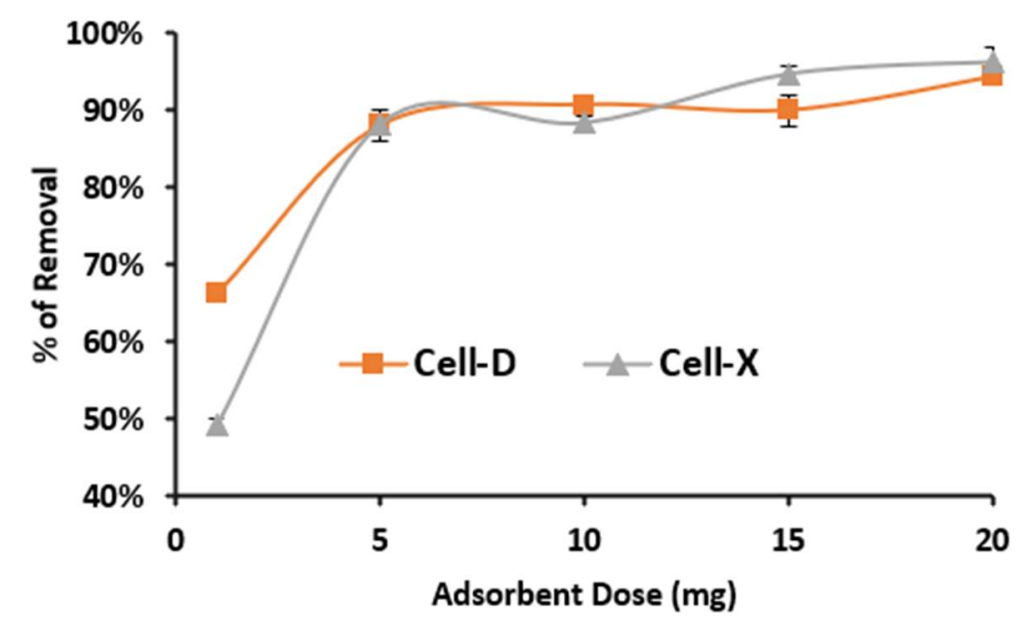

Figure 8. Effect of adsorbent dose on adsorption efficiency of Cell-X and Cell-D. (Volume: $10 \mathrm{~mL}$, $20^{\circ} \mathrm{C}, \mathrm{pH}: 6$ and 8 for Cell-X and Cell-D, respectively). 


\subsection{Adsorption Isotherm}

Two adsorption isotherm models were evaluated for the current adsorption process Freundlich and Langmuir isotherms [35]. Adsorption kinetic was also conducted using three different models: pseudo-first order, pseudo-second-order and intra-particlediffusion. A Van't Hoff graph was plotted to determine the thermodynamic terms $\Delta \mathrm{H}$, $\Delta \mathrm{G}$ and $\Delta \mathrm{S}$, whose values give an indication of the thermal dependence of the process (spontaneous at room temperature, or endothermic).

\subsubsection{Langmuir Adsorption Model}

The Langmuir model represents the chemisorption process. It is assumed that the adsorption sites all have the same amount of energy [36]. This model is presented in Equation (1).

$$
\frac{\mathrm{C}_{\mathrm{e}}}{\mathrm{q}_{\mathrm{e}}}=\frac{1}{\mathrm{bQ}_{\mathrm{o}}}+\frac{1}{\mathrm{Q}_{\mathrm{o}}} \mathrm{C}_{\mathrm{e}}
$$

where $\mathrm{C}_{\mathrm{e}}$ : equilibrium difenoconazole concentration $\left(\mathrm{mg} \mathrm{L}^{-1}\right), \mathrm{Q}_{\mathrm{o}}$ : adsorption capacity at equilibrium (mg/g), qe: amount of difenoconazole divided by the polymer mass $(\mathrm{mg} / \mathrm{g})$, b: Langmuir affinity constant $(\mathrm{L} / \mathrm{mg})$, and a graph of $\left(\mathrm{C}_{\mathrm{e}} / \mathrm{q}_{\mathrm{e}}\right)$ versus $\mathrm{C}_{\mathrm{e}}$ results in slope $\left(1 / \mathrm{Q}_{\mathrm{o}}\right)$ and y-intercept $\left(1 / \mathrm{bQ}_{\mathrm{o}}\right)[35,36]$.

\subsubsection{Freundlich Adsorption Model}

This model assumes adsorption on heterogeneous surfaces of or on surfaces with sites of various affinities. The Freundlich isotherm detects that strong binding sites are occupied first, in which the binding strength decreases with the increasing degree of site occupation. This adsorption model is presented in Equation (2) [36].

$$
\log q_{e}=\log K_{F}+\frac{1}{n} \log C_{e}
$$

where $\mathrm{n}$ is the heterogeneity coefficient, and from its value it can be concluded if an adsorption is favorable or not $(\mathrm{g} / \mathrm{L}) ; \mathrm{K}_{\mathrm{F}}$ : Freundlich Isotherm constant $(\mathrm{mg} / \mathrm{g})$. Equation (2) represents a straight line equation, so plotting $\log \mathrm{q}_{\mathrm{e}}$ versus $\log \mathrm{C}_{\mathrm{e}}$ results in $\log \mathrm{K}_{\mathrm{F}}$ as an intercept and slope equal to $1 / \mathrm{n}$ [36]. Difenoconazole adsorption by Cell-X or Cell-D was fitted to Langmuir and Freundlich isotherms, the results are shown in Figures 9 and 10, and the isotherm parameters are shown in Table S1. Results detect that difenoconazole adsorption fitted to Langmuir adsorption, since $\mathrm{R}^{2}$ of Cell-X and Cell-D were very close to 1 .
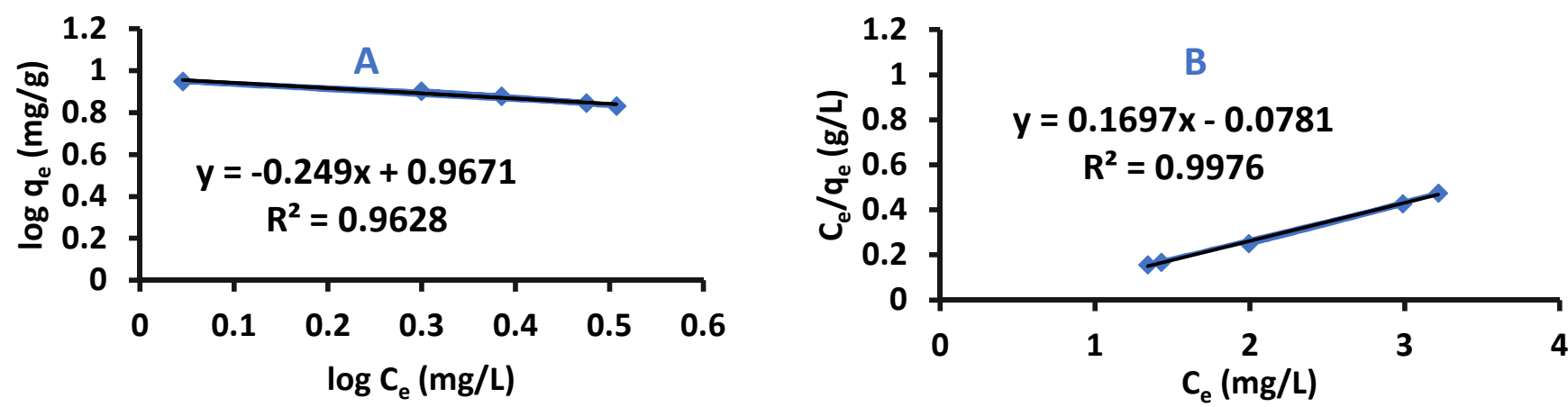

Figure 9. (A) Freundlich and (B) Langmuir plots for difenoconazole by Cell-D (pH: 4, volume: $10 \mathrm{~mL}$, temperature: $20^{\circ} \mathrm{C}$, adsorption time: $15 \mathrm{~min}$, dosage: $10 \mathrm{mg}$ ).

The values of $\mathrm{R}^{2}$ obtained by Langmuir isotherm were close to 1 , an indication of the high affinity for Cell-X and Cell- D of difenoconazole, and the adsorption process follows the Langmuir isotherm model. 

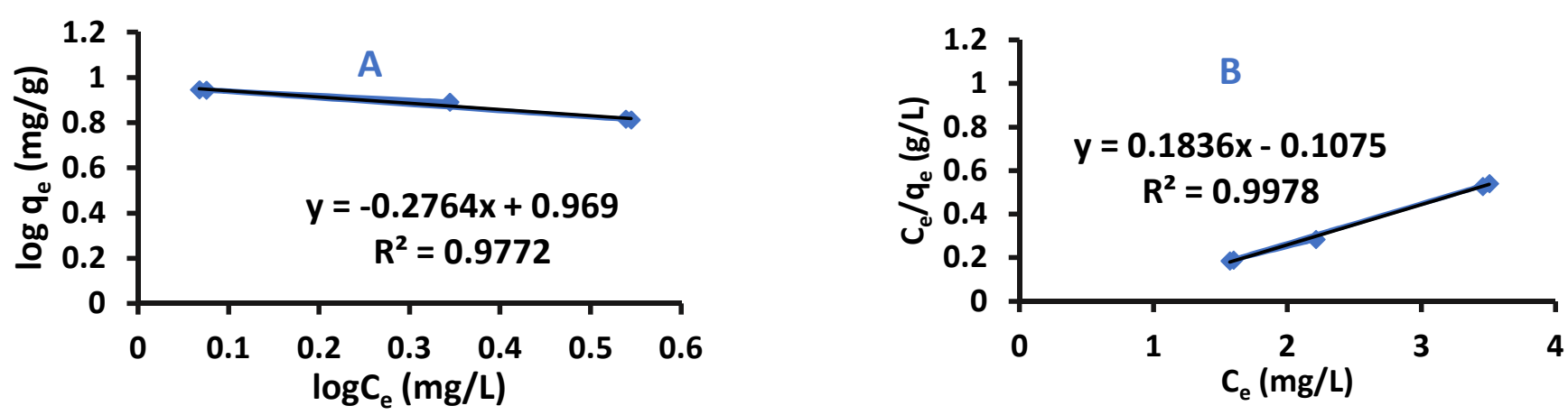

Figure 10. (A) Freundlich (B) Langmuir plots for difenoconazole by Cell-X (pH: 6, volume: $10 \mathrm{~mL}$, temperature: $20{ }^{\circ} \mathrm{C}$, adsorption time: $20 \mathrm{~min}$, dosage: $10 \mathrm{mg}$ ).

\subsubsection{Adsorption Kinetic Models}

Kinetic models can be used to determine the adsorption mechanism of removal of adsorbate by adsorbent, and whether the adsorption process is chemically or physically controlled. The adsorption kinetic models that are evaluated in this work were pseudofirst-order, pseudo-second-order and Intra-Particle-Diffusion-Kinetics [37-39].

Pseudo-First-Order-Kinetics

The Pseudo-First-Order equation is presented below

$$
\log \left(\mathrm{q}_{\mathrm{e}}-\mathrm{q}_{\mathrm{t}}\right)=\log \mathrm{q}_{\mathrm{e}}-\frac{\mathrm{K}_{1}}{2.303} \mathrm{t}
$$

where $\mathrm{q}_{\mathrm{e}}$ and $\mathrm{q}_{\mathrm{t}}$ are the masses of difenoconazole per adsorbent mass unit at equilibrium at time $\mathrm{t}$, respectively, the units or the terms are $(\mathrm{mg} / \mathrm{g})$, and $\mathrm{k}_{1}$ is the rate adsorption constant of pseudo-first-order kinetic $\left(\mathrm{mg} \mathrm{g}^{-1} \mathrm{~min}^{-1}\right)$.

Plotting $\log \left(\mathrm{q}_{\mathrm{e}}-\mathrm{q}_{\mathrm{t}}\right)$ versus time must produce a straight line with $\log \mathrm{q}_{\mathrm{e}}$ as y-intercept and $\left(-\mathrm{k}_{1} / 2.303\right)$ as slope [40].

Pseudo-Second-Order-Kinetics

This model shows that the rate-determining step can be fitted to a chemical adsorption process in which the electrons can be shared or exchanged between the pesticide and the adsorbent. The pseudo-second-order-model is presented in Equation (4):

$$
\frac{\mathrm{t}}{\mathrm{q}_{\mathrm{t}}}=\frac{1}{\mathrm{k}_{2} \mathrm{q}_{\mathrm{e}}^{2}}+\frac{1}{\mathrm{q}_{\mathrm{e}}} \mathrm{t}
$$

Where $\mathrm{k}_{2}$ is the rate adsorption constant of pseudo-second-order-kinetic at equilibrium with a unit of: $\mathrm{g} \mathrm{mg}^{-1} \mathrm{~min}^{-1}$. The graph-produced form plotting $\mathrm{t} / \mathrm{q}_{\mathrm{t}}$ versus $\mathrm{t}$ results in a straight line with a slope of $1 / \mathrm{q}_{\mathrm{e}}$ and y-intercept $1 / \mathrm{k}_{2} \mathrm{q}_{\mathrm{e}}{ }^{2}$.

Intra-Particle-Diffusion-Kinetics

This model was suggested by Weber and Morris and is shown in Equation (5):

$$
\mathrm{q}_{\mathrm{t}}=\mathrm{K}_{\mathrm{p}} \mathrm{t}^{0.5}+\mathrm{C}
$$

where $K_{\mathrm{p}}$ is the rate adsorption constant $\left(\mathrm{mg} / \mathrm{g} \mathrm{min}^{1 / 2}\right)$, and $\mathrm{C}$ is a constant that depends on the thickness of the boundary layer $(\mathrm{mg} / \mathrm{g})$ [41].

A graph of $q_{t}$ versus $t^{1 / 2}$ represents an intra-particle-diffusion model graph where $C$ is $y$-intercept and $K_{p}$ is slope [41,42].

The kinetic experimental data for adsorption of difenoconazole pesticide by Cell-X and Cell-D were fitted to intra-particle-diffusion, pseudo-first-order, and pseudo-secondorder models to study the mechanism of each adsorption. Results are presented in Figures 11 and 12. 

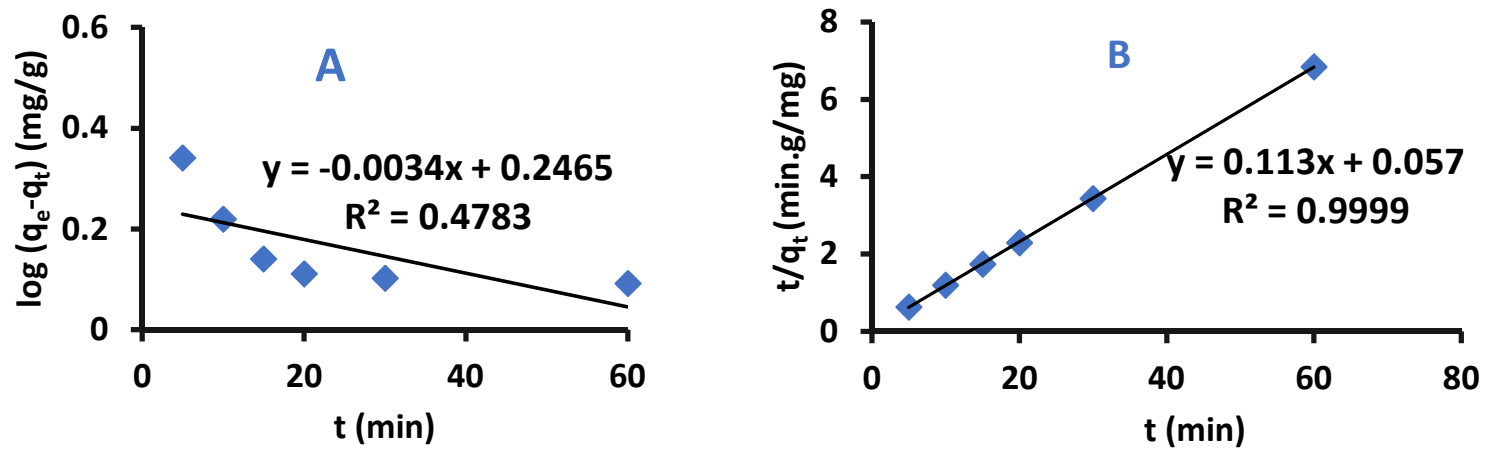

C

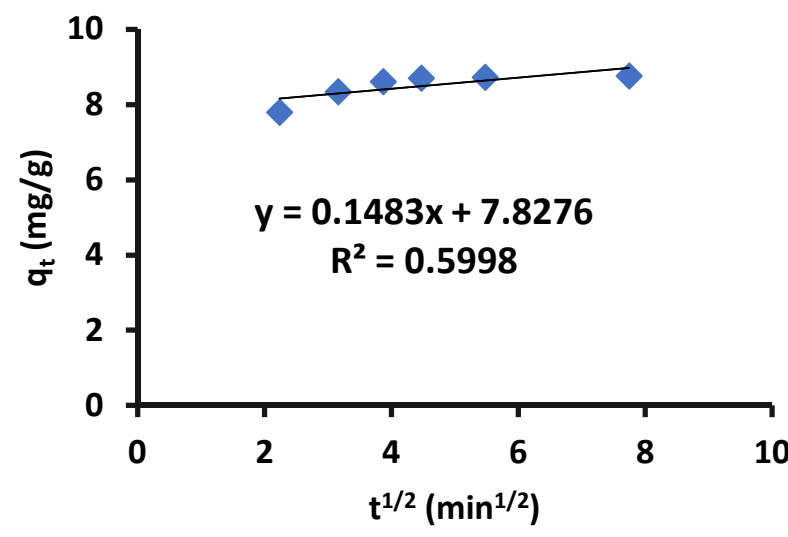

Figure 11. Pseudo-first-order (A), Pseudo-second-order (B), and Intra-particle-diffusion kinetic (C) of difenoconazole removal by Cell-D ( $\mathrm{C}_{\mathrm{I}}: 10 \mathrm{ppm}$, volume: $10 \mathrm{~mL}$, temperature: $20^{\circ} \mathrm{C}, \mathrm{pH}: 7$, dose: $\left.10 \mathrm{mg}\right)$.
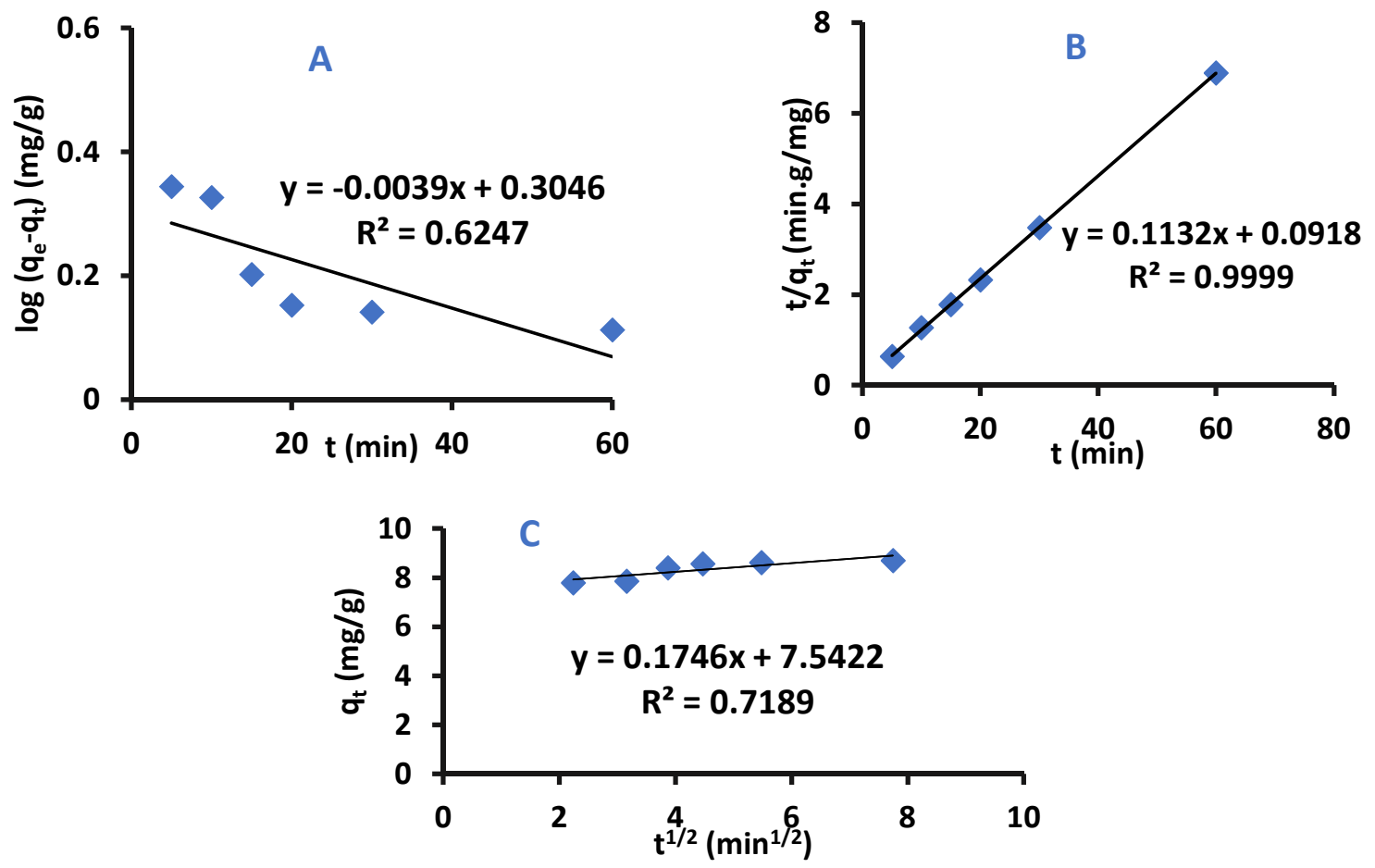

Figure 12. Pseudo-first-order (A), Pseudo-second-order (B), and Intra-particle-diffusion kinetic (C) for difenoconazole removal by Cell-X. ( $\mathrm{C}_{\mathrm{I}}: 10 \mathrm{ppm}$, volume: $10 \mathrm{~mL}, \mathrm{pH}: 7$, temperature: $20^{\circ} \mathrm{C}$, dose $\left.=10 \mathrm{mg}\right)$. 
The $\mathrm{q}_{\mathrm{e}}$ calculated and experimental method are shown in Table S2, and comparison between these values shows that the adsorption of difenoconazole by Cell- $X$ and Cell-D follows the pseudo-second-order-kinetics and indicates a strong bonding between difenoconazole and adsorbent.

\subsubsection{Adsorption Thermodynamics}

Thermodynamic study is required to determine if the adsorption process is spontaneous at room temperature or not. The Change in Enthalpy $(\Delta \mathrm{H})$, Entropy $(\Delta \mathrm{S})$ and Gibbs free energy $(\Delta G)$ were calculated [42-45] using Equations (6)-(8).

$$
\begin{gathered}
\Delta \mathrm{G}=\Delta \mathrm{H}-\mathrm{T} \Delta \mathrm{S} \\
\Delta \mathrm{G}=-\mathrm{RT} \times \mathrm{InK}_{\mathrm{d}}
\end{gathered}
$$

where $\mathrm{R}$ has a value $8.314 \mathrm{~J} \mathrm{~mol}^{-1} \mathrm{~K}^{-1}$ and represents universal gas constant, $\mathrm{K}_{\mathrm{d}}$ : thermodynamic equilibrium constant that equals $\left(\mathrm{q}_{\mathrm{e}} / \mathrm{C}_{\mathrm{e}}\right)$ with a unit of mol or $\mathrm{L} \mathrm{g}^{-1}$.

Results of Equations (6) and (7) are combined in Equation (8).

$$
\ln K_{d}=\frac{\Delta S}{R}-\frac{\Delta H}{R T}
$$

A graph of InK $K_{d}$ versus $(1 / T)$ (Van't Hoff plot) was plotted, the slope representing $\Delta \mathrm{H} / \mathrm{R}$ and $\mathrm{y}$-intercept representing $\Delta \mathrm{S} / \mathrm{R}[46]$. This graph was used for determining the thermodynamic parameters $\left(\Delta \mathrm{G}^{\circ}, \Delta \mathrm{S}\right.$ and $\left.\Delta \mathrm{H}\right)$ for difenoconazole removal by Cell- $\mathrm{X}$ and Cell-D. The plots are shown in Figure 13 and the obtained difenoconazole thermodynamic parameters are shown in Table S3.

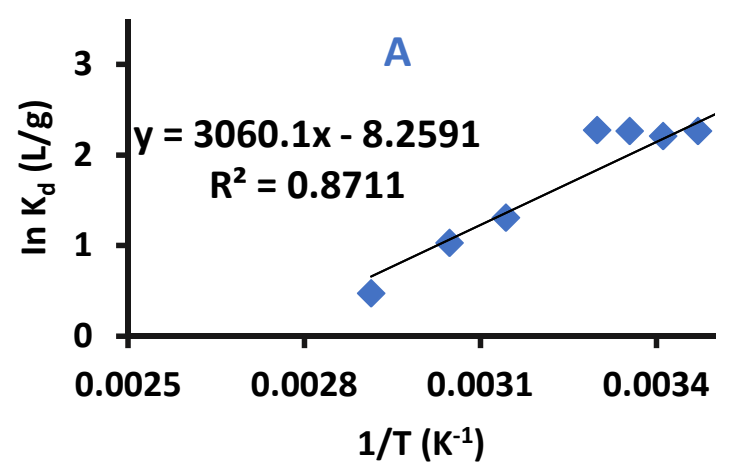

(a)

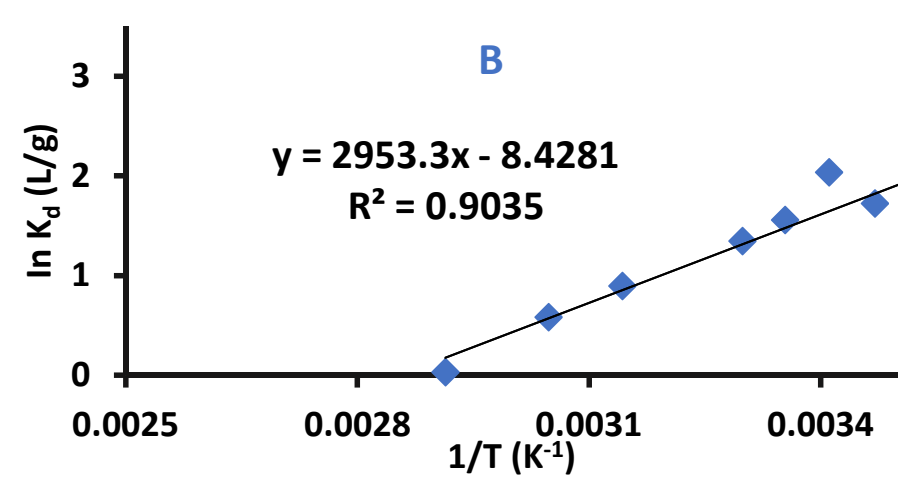

(b)

Figure 13. Van't Hoff plots for the adsorption of difenoconazole by (A) Cell-D (CI: 10 ppm, pH: 8, time: 20 min), (B) Cell-X (C $\mathrm{I}: 8$ ppm, pH: 6, time: $60 \mathrm{~min})$, (dosage: $10 \mathrm{mg}$, volume: $10 \mathrm{~mL}$ ).

The values of $\Delta \mathrm{H}$ and $\Delta \mathrm{G}^{\circ}$ indicate that the adsorption of difenoconazole by Cell-X and Cell-D is spontaneous and exothermic. In addition, negative $\Delta S$ indicates the existence of an associative mechanism, in which no significant change will appear in the polymer's internal structure during adsorption.

\subsection{Adsorbents Regeneration}

The regeneration of adsorbents was carried out by rinsing with a solution of $\mathrm{H}_{2} \mathrm{SO}_{4}$ $(0.1 \mathrm{~N})$, distilled water, and ethanol to ensure completed removal of difenoconazole. Results for three adsorption cycles are shown in Figure 14 and show a small drop in removal efficiency. These results are after the first cycle. This is an indication that the Cell- $X$ and Cell-D cellulose based polymers could be promising materials for removing difenoconazole and other persistent pesticides from water to a drinkable degree. 


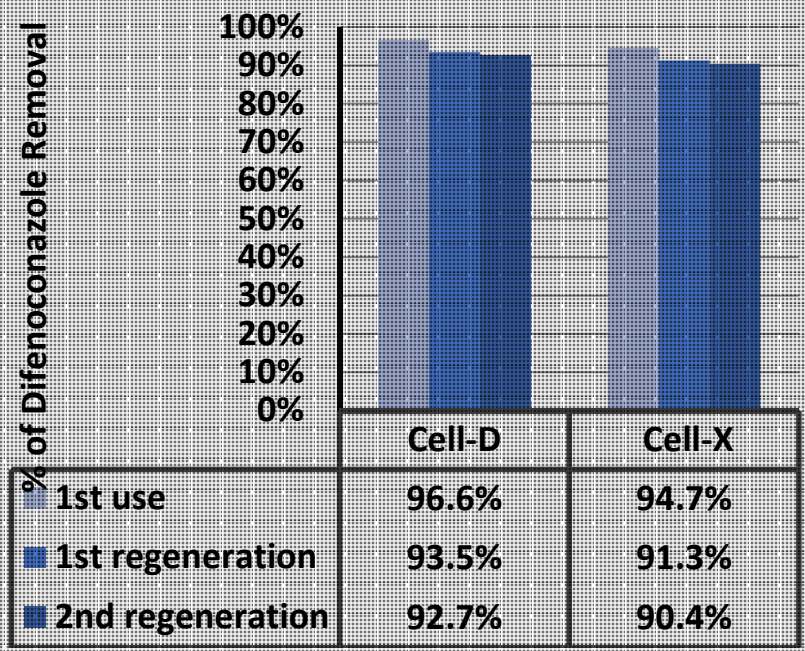

Figure 14. Adsorbent recycling results.

A representative scheme showing the interaction between Cell- $\mathrm{X}$ and difenoconazole is seen in Figure 15A. The scheme explains the high affinity of Cell- $X$ to difenoconazole, the main interaction force is $\mathrm{H}$-binding, and other forces contributing to the strong interaction are $\pi-\pi$ stacking between the pi-electrons of difenoconazole and the aryl part of 2,6pyridine di-carbonyl attached to cellulose polymer chain. As mentioned earlier, Cell- $\mathrm{X}$ has a semi crown ether structure where cavities are created in the middle (Figure 15A) and difenoconazole passes through the adsorbent pores and becomes trapped in the cavities (inclusion) $[47,48]$.
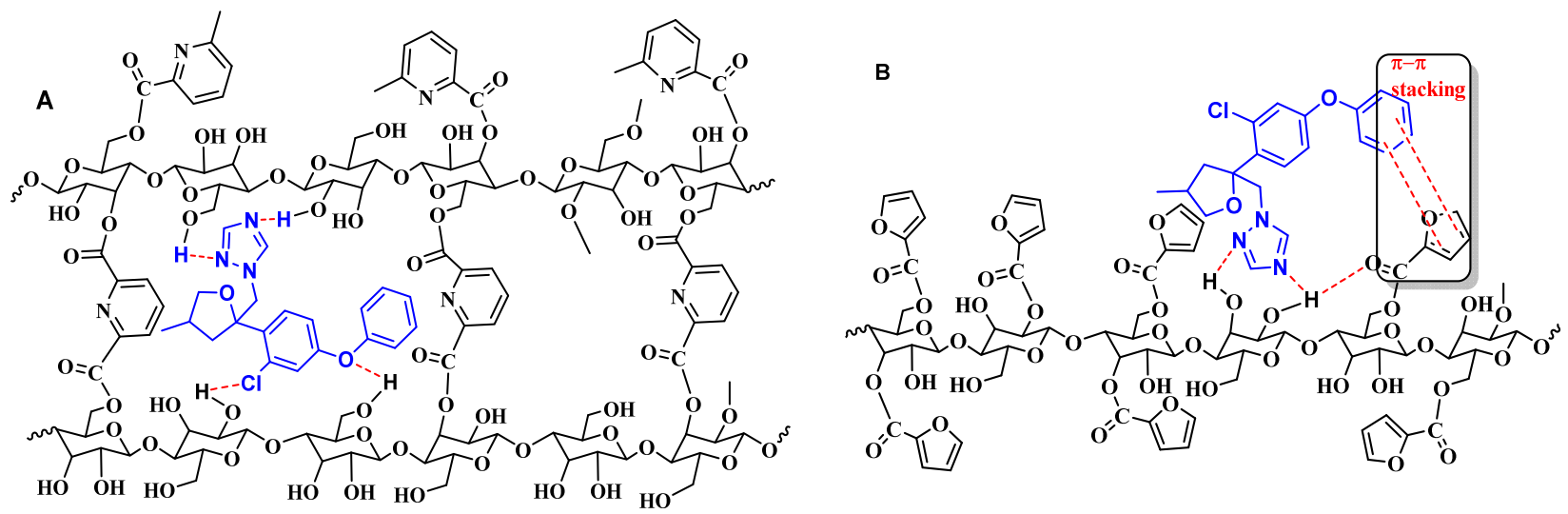

Figure 15. A representative structure shows the interaction between, (A) Cell-X and difenoconazole; (B) Cell-D and difenoconazole.

Cell-D also showed high affinity to difenoconazole, and a representative scheme showing the interaction between Cell-D and difenoconazole is presented in Figure 15B; the main interaction forces between the sorbent and the adsorbate are H-binding and $\pi-\pi$ stacking between the pi-electrons of difenoconazole and the furyl part of 2-furan carbonyl, bonded to the cellulose polymer backbone. Cell-X showed an extra major attraction force which is not present in Cell-D.

\subsection{Monte Carlo (MC) and Molecular Dynamic (MD) Simulation}

In Figure 16 the lowest energy configurations for the cellulose surface and the difenoconazole molecule are presented. The assessable decision on the interaction between 
the difenoconazole molecule Cell-X polymer surface is executed by calculation of the adsorption energies using the following Equation (9):

$$
E_{a d s}=E_{\text {total }}-\left[E_{\text {difenoconazole }}+E_{(\text {name }) \text { surface }}\right]
$$

where $E_{\text {total }}$ is the total energy of the system as a result of interaction between Cell-X surface and the difenoconazole molecule; $E_{\text {difenoconazole }}$ and $E_{\text {(name) surface }}$ is the system's energy in the absence and presence of difenoconazole.

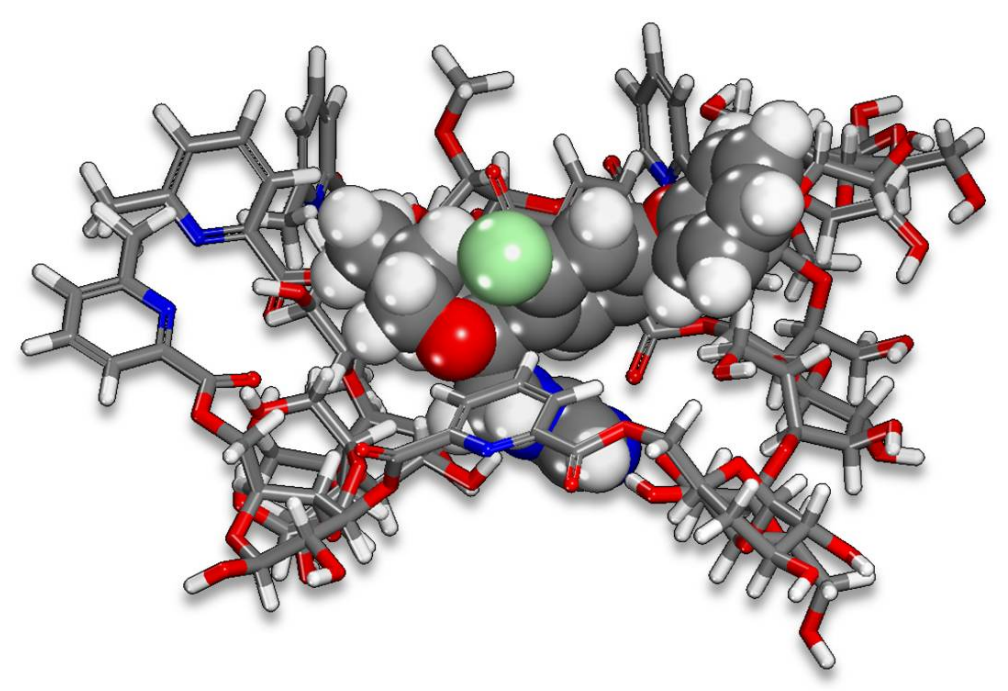

Figure 16. MC pose of the lowest adsorption configurations for the difenoconazole molecule onto the Cell-X surface.

The lowest energy pose from MC calculations is obtained through a vast number of randomized configurations. The indications for obtaining the lowest energy pose are evident in Figure 17a (the average energy is remained unchanged-indicated by the yellow box in the Figure 17a). The Monte Carlo calculations (Figure 16) are in good agreement with the experimental results, where the difenoconazole strongly adsorbs onto the cellulose surface. The negative value of the adsorption supports the spontaneity of the adsorption process onto this material [47]. The distribution of the adsorption energies is in a range from $-0.5--37.05 \mathrm{kcal} / \mathrm{mol}$, as shown in the Figure $17 \mathrm{~b}$. In general, MD is more reliant on monitoring and recording the process's dynamics. As indicated by the slight temperature drift on the graph in the Figure 17c, the equilibrium configuration is attained. Figure 18 depicts the time evolution of the lowest equilibrium energy structure for the interaction of the difenoconazole molecule onto a surface. The interaction (adsorption) energy during the MD is evaluated at each time elapse and is presented in Figure 19. The flexibility of the Cell-X surface chains during the difenoconazole interaction causes energy fluctuation throughout the MD. As seen from Table 1, the mean value of the adsorption energy of the difenoconazole molecule onto Cell- $X$ surface during the MD is $-86.96 \mathrm{kcal} / \mathrm{mol}$. 

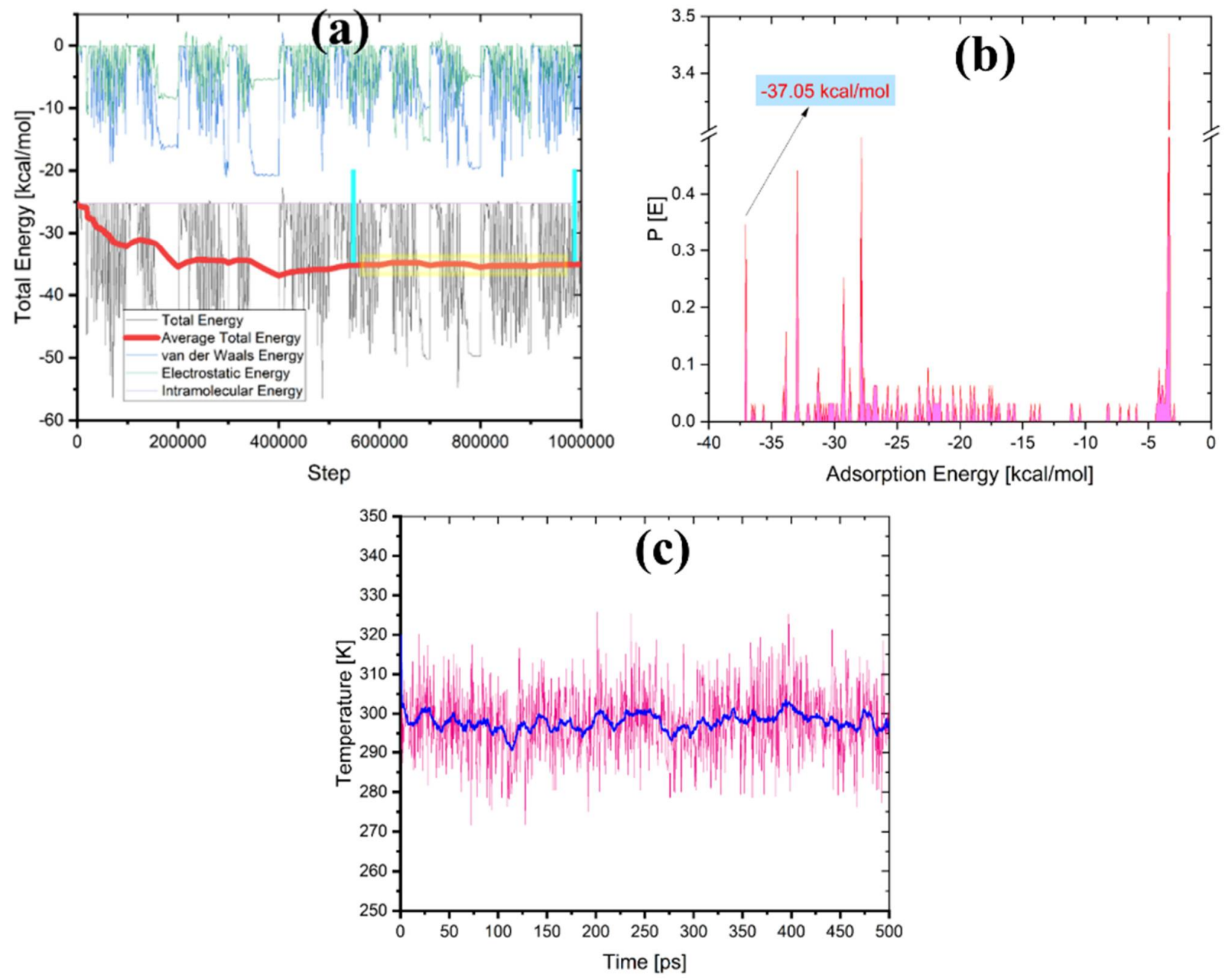

Figure 17. (a) Energy terms during the search for the MC pose of the lowest adsorption configurations for the difenoconazole molecule onto Cell-X surface, (b) Distribution of the adsorption energies for the difenoconazole molecule onto Cell- $X$ surface gained via $\mathrm{MC}$ and (c) graph of temperature control from MD during the interaction of the difenoconazole molecule onto Cell-X surface.

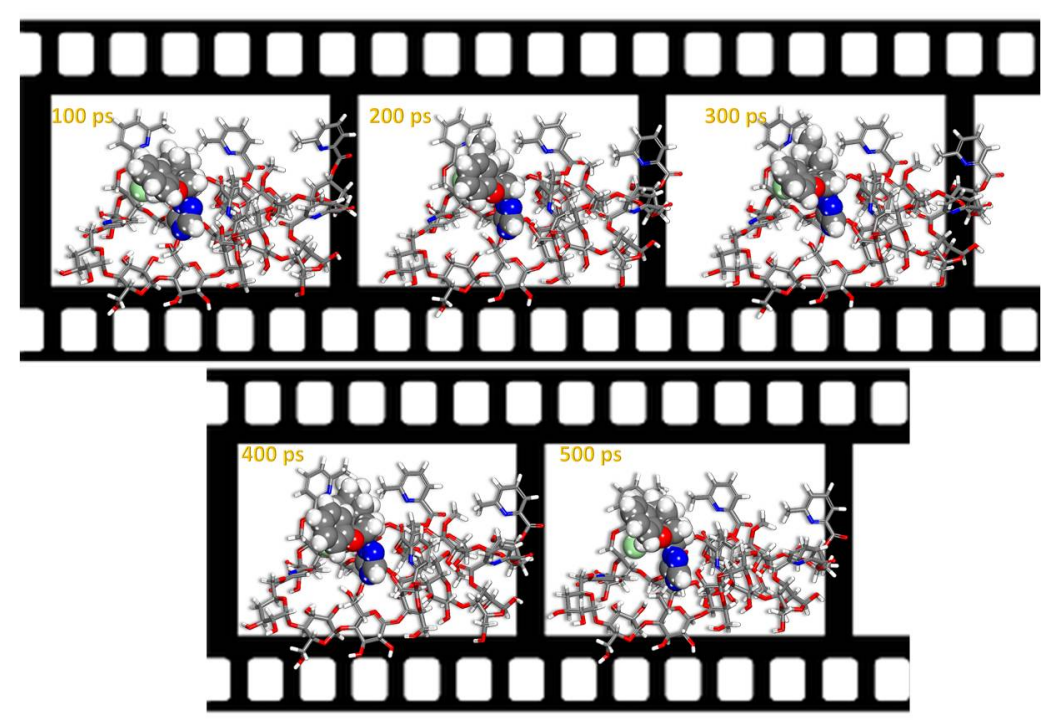

Figure 18. Time-lapse configurations of the interaction of the difenoconazole molecule onto Cell-X surface obtained by MD. 


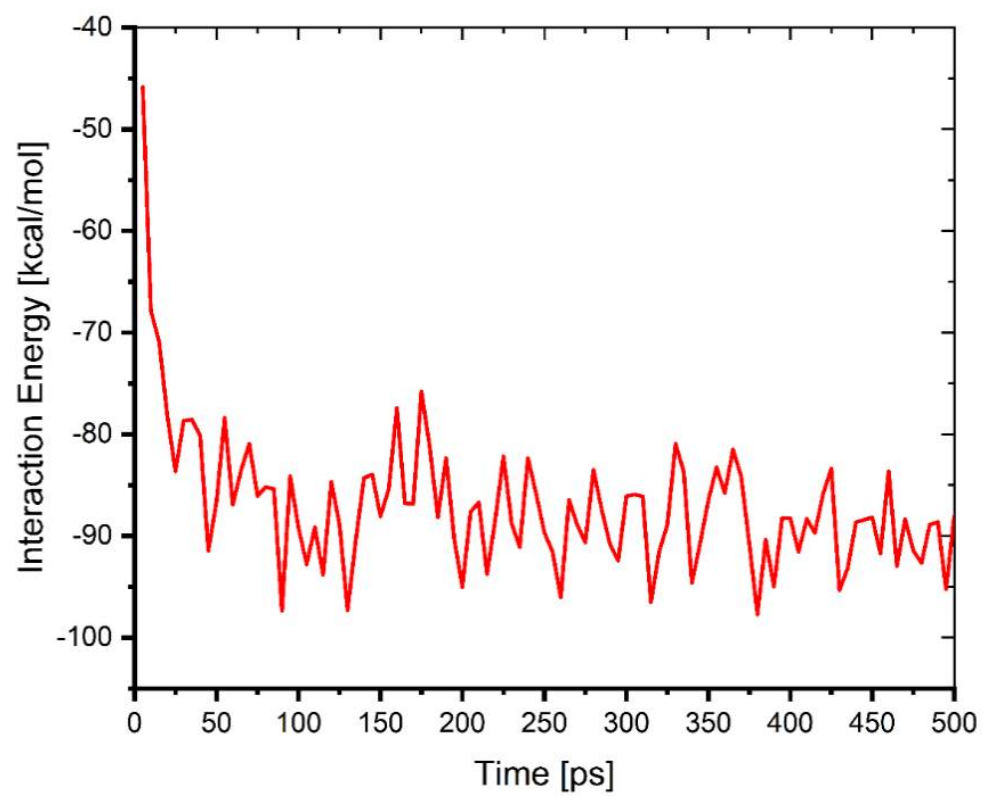

Figure 19. The interaction energy of the difenoconazole molecule onto Cell-X surface during MD. The results show that there are bonding sites on the polymer surface, the difenoconazole molecule fits well and interacts strongly with functional groups present at the bonding sites, and the interaction is strong and stable. The Langmuir Adsorption model also shows that the difenoconazole molecules are equally and homogeneously spread over the polymer surface.

Table 1. Statistics for the interaction energy of the difenoconazole molecule onto Cell-X surface during MD.

\begin{tabular}{ccccc}
\hline Mean & $\begin{array}{c}\text { Standard } \\
\text { Deviation }\end{array}$ & Minimum & Median & Maximum \\
\hline-86.9644 & 6.81479 & -97.71934 & -88.10748 & -45.8472 \\
\hline
\end{tabular}

\section{Materials and Methods}

\subsection{Chemicals}

All chemicals were obtained from Aldrich Chemical Company in Munich, Germany and used without any further purification. They include anhydrous lithium chloride, anhydrous dimethylacetamide, difenoconazole, 2,6-pyridine dicarbonyl dichloride and 2-furan carbonyl chloride.

\subsection{Methods}

The NMR spectra were recorded on a Bruker $600 \mathrm{MHz}$ spectrometer, equipped with a $5 \mathrm{~mm}$ broadband CryoProbe Prodigy. The acquisition parameters are: $90^{\circ}$ pulse calibrated at $12 \mu \mathrm{s}, 1.3 \mathrm{~s}$ acquisition time, $2 \mathrm{~s}$ time of relaxation, no spinning, $300 \mathrm{~K}$, and 2048 scans. The proton NMR spectra were obtained at Forschungszentrum Jülich (Juelich, Germany). The FT-IR spectrum was recorded using FT-IR spectrometry, Nicolet iS5, iD3 with ATR (Thermo Scientific, Japan). Thermogravimetric measurements were carried out using the TGA, Q50 V20.10, Build 36 instrument at a heating rate of $10{ }^{\circ} \mathrm{C} / \mathrm{min}$ under $\mathrm{N}_{2}$ gas. The polymer morphologies were investigated using scanning electron microscopy (SEM, Tubney Woods, JEOL 7400F Oxford Instruments Inca, Abingdon, Oxon OX13 5QX, UK).

High Performance Liquid Chromatography (HPLC) was carried out on Waters 1525 Binary HPLC Pump with Photodiode Array Detector PAD (Waters 2998, USA). Data were analyzed using Breeze QS software with the X TERRA C18 column, $5 \mu \mathrm{m}, 250 \mathrm{~mm} \times 4.6 \mathrm{~mm}$, at a flow rate of $1 \mathrm{~m} / \mathrm{min}$. The mobile phase was a combination of $36 \%$ distilled water and $64 \%$ acetonitrile. 


\subsection{Crosslinking of Cellulose with Pyridine 2,6-Dicarbonyl Dichloride (Cell-X)}

A cellulose solution was first prepared by the dissolution process reported in the literature [49]. Cellulose was first activated by suspending a $1.2 \mathrm{~g}(7.4 \mathrm{mmol} /$ anhydroglucose unit (AGU) of in $100 \mathrm{~mL}$ of distilled water. The suspension was mixed for $2 \mathrm{~h}$ at ambient temperature. Cellulose was then collected by suction filtration and resuspended in methanol $(100 \mathrm{~mL})$ for $1 \mathrm{~h}$ to remove water. To ensure the complete removal of water, the procedure was repeated twice, followed by two successive solvent exchange $(25 \mathrm{~mL}$ each) with DMAc. The first exchange was performed for $1.0 \mathrm{~h}$, while the second exchange was carried out for $24 \mathrm{~h}$. After each solvent exchange, DMAc was removed by suction filtration. The activation stage at this step was completed and the dissolution of activated cellulose was carried out in a two-necked-round bottomed flask fitted with a condenser. To the cellulose in the flask a solution of anhydrous $\mathrm{LiCl}(6.5 \mathrm{~g})$ was added in a $100 \mathrm{~mL}$ anhydrous DMAc. The suspension was stirred until a clear gel was obtained (about $2 \mathrm{~h}$ ). To the cellulose solution, trimethylamine $(0.5 \mathrm{~mL})$ was added dropwise under nitrogen, followed with a solution of 2,6-pyridine di-carbonyl dichloride $(2.448 \mathrm{~g}, 12 \mathrm{mmol})$ in a $10 \mathrm{~mL}$ DMAc anhydrous. The produced solution was heated for $3 \mathrm{~h}$ at $70^{\circ} \mathrm{C}$. The produced precipitate was collected by suction filtration and washed several times with distilled water and ethanol, then dried at room temperature for $24 \mathrm{~h}$.

\subsection{Acylation of Cellulose with Furan-2-Carbonyl Chloride (Cell-D)}

The above experiment (2.3) was repeated exactly, except that a solution of furan-2carbonyl chloride ( $2.86 \mathrm{~g}, 22.0 \mathrm{mmol})$ in $10 \mathrm{~mL}$ anhydrous DMAc was used.

\subsection{Difenoconazole Adsorption Experiments}

Batch experiments were done in plastic vials $(50 \mathrm{~mL})$ placed in a shaker immersed in a water bath equipped with thermostat. Solution effects such as $\mathrm{pH}$, time, dosage, difenoconazole initial concentration and temperature effect on the polymer's efficiency were studied. After each run, the sample was collected using a $10 \mathrm{~mL}$ plastic syringe, then filtered through a $0.45 \mu \mathrm{m}$ filter and subjected to HPLC analysis at $229 \mathrm{~nm}$ wavelength to calculate the residual pesticide amount after adsorption. All difenoconazole adsorption experiments were performed in triplicate, and the average of the three runs was determined. The difenoconazole adsorbed amount on Cell-X and Cell-D was then determined using Equations (10) and (11), respectively.

$$
\begin{gathered}
\mathrm{R}(\%)=\frac{\mathrm{C}_{0}-\mathrm{C}_{\mathrm{e}}}{\mathrm{C}_{0}} \\
\mathrm{Q}_{\mathrm{e}}=\frac{\mathrm{C}_{0}-\mathrm{C}_{\mathrm{e}}}{\mathrm{m}} \mathrm{V}
\end{gathered}
$$

where $\mathrm{C}_{0}$ and $\mathrm{C}_{\mathrm{e}}$ : Initial and equilibrium concentrations (ppm) of difenoconazole in solution, respectively, V: solution volume $(\mathrm{mL}), \mathrm{m}$ : adsorbent dose $(\mathrm{mg})$, and $\mathrm{Q}_{\mathrm{e}}$ : equilibrium adsorption capacity (mg/L).

\subsection{Monte Carlo (MC) and Molecular Dynamic (MD) Simulation}

The interaction between the surface and the difenoconazole molecule was investigated in the vacuum using a large number of randomized Monte Carlo steps $(975,956,401$ configurations). The MD calculations continued to use the lowest energy pose provided by MC. Prior to the MD stage, the geometry of the simulation boxes was optimized (tolerance for energy convergence of $1 \times 10^{-5} \mathrm{kcal} / \mathrm{mol}$; atom-based summation method used for both electrostatic and van der Waals interactions with a cutoff distance of 15.5, a spline width of 1 , and a 0.5 buffer) using the Forcite module included in the Biovia software. MD was performed at $25^{\circ} \mathrm{C}$ using the constant volume/constant temperature (NVT) canonical ensemble with a simulation time of $500 \mathrm{ps}$ ( $1 \mathrm{fs}$ time step) [50-53]. The Berendsen thermostat maintained the T control. Calculations for MC and MD were performed using the Condensed Phase Optimized Molecular Potential II (COMPASSII) forcefield [54-59]. 


\section{Conclusions}

Two cellulosic based heterocyclic nano-polymers were prepared by reacting nanocrystalline cellulose with the crosslinking agent 2,6-pyridine di-carbonyl dichloride (Cell-X) and 2-furan carbonyl chloride (Cell-D). The structures of the synthesized polymers were characterized by SEM, TGA, proton NMR and FT-IR spectroscopy. The prepared polymers Cell-X and Cell-D were evaluated as adsorbents for removal of difenoconazole from water. The adsorption efficiency was studied as a function of $\mathrm{pH}$ value, contact time, temperature, adsorbent dose, and initial concentration of difenoconazole. The results were used to determine the optimum adsorption efficiency. The results show that the percentage removal of difenoconazole pesticide form water using Cell-X and Cell-D can be quantitative. The adsorption mechanism was predicted by Langmuir isotherm model. Kinetic data revealed that the adsorption of difenoconazole obeys the pseudo second order. Thermodynamic data showed free energies with negative values, indicating a spontaneous adsorption process of difenoconazole by Cell-X and Cell-D. Theoretical calculation using Monte Carlo (MC) and Molecular Dynamic (MD) simulation models were conducted to confirm the experimental results of strong interaction and spontaneous adsorption between difenoconazole and the adsorbents.

Supplementary Materials: The following are available online at https://www.mdpi.com/article/ 10.3390/ijms22116090/s1. Figure S1. FT-IR analysis for Cell-D. Figure S2. H1 NMR analysis for Cell-D dissolved in DMSO-d6. Figure S3. TGA analysis for A: Cell-D and B: Cell-X. Table S1. Parameters of Langmuir and Freundlich isotherms for Difenoconazole by Cell-X and Cell-D. Table S2. Pseudo-first-order, pseudo-second-order and intra-particle-diffusion kinetic adsorption parameters of Dif-enoconazole removal by Cell-X or Cell-D.

Author Contributions: O.H. and S.J. generated the idea; B.K. conceived the experimental part. Z.S. and A.B. studied the theoretical results. G.H. and O.D. explained some results. R.B. and S.S. helped in financial aid and explained some results. All authors have read and agreed to the published version of the manuscript.

Funding: The funding was from the Middle East Research Center as scholarship support for Ph.D. program and also from the German Federal Ministry of Education and Research (BMBF) and carried out by Palestinian Academy for Science and Technology (PALAST) and Forschungszentrum Jülich. Special thanks goe to the IDG institute for helping us using NMR.

Institutional Review Board Statement: Not applicable.

Informed Consent Statement: Not applicable.

Data Availability Statement: Not applicable.

Acknowledgments: Special thanks to Erwin. Klumpp, Nina Siebers and Liming Wang at Institute of Bio and Geosciences, Forschungszentrum Jülich, Germany for their help in analysis analysis.

Conflicts of Interest: The authors declare no conflict of interest.

\section{References}

1. Damalas, C.A.; Koutroubas, S.D. Farmers' Exposure to Pesticides: Toxicity Types and Ways of Prevention. Toxics 2016, 4, 1. [CrossRef] [PubMed]

2. Kalia, A.; Gosal, S. Effect of pesticide application on soil microorganisms. Arch. Agron. Soil Sci. 2011, 57, 569-596. [CrossRef]

3. Lafi, W.K.; Al-Qodah, Z. Combined advanced oxidation and biological treatment processes for the removal of pesticides from aqueous solutions. J. Hazard. Mater. 2006, 137, 489-497. [CrossRef] [PubMed]

4. Barros, A.; Pizzolato, T.; Carissimi, E.; Schneider, I. Decolorizing dye wastewater from the agate industry with Fenton oxidation process. Miner. Eng. 2006, 19, 87-90. [CrossRef]

5. Bai, Y.; Chen, J.; Yang, Y.; Guo, L.; Zhang, C. Degradation of organophosphorus pesticide induced by oxygen plasma: Effects of operating parameters and reaction mechanisms. Chemosphere 2010, 81, 408-414. [CrossRef]

6. Özer, A.; Akkaya, G.; Turabik, M. The biosorption of Acid Red 337 and Acid Blue 324 on Enteromorpha prolifera: The application of nonlinear regression analysis to dye biosorption. Chem. Eng. J. 2005, 112, 181-190. [CrossRef]

7. Ling, S.; Qin, Z.; Huang, W.; Cao, S.; Kaplan, D.L.; Buehler, M.J. Design and function of biomimetic multilayer water purification membranes. Sci. Adv. 2017, 3, e1601939. [CrossRef] 
8. Liu, C.-C.; Hsieh, Y.-H.; Lai, P.-F.; Li, C.-H.; Kao, C.-L. Photodegradation treatment of azo dye wastewater by UV/TiO2 process. Dye. Pigment. 2006, 68, 191-195. [CrossRef]

9. Ikehata, K.; El-Din, M.G. Aqueous pesticide degradation by ozonation and ozone-based advanced oxidation processes: A review (Part I). Ozone Sci. Eng. 2005, 27, 83-114. [CrossRef]

10. Qiu, Z.; He, Y.; Liu, X.; Yu, S. Catalytic oxidation of the dye wastewater with hydrogen peroxide. Chem. Eng. Process. Process. Intensif. 2005, 44, 1013-1017. [CrossRef]

11. Yang, H.Y.; Han, Z.J.; Yu, S.F.; Pey, K.L.; Ostrikov, K.; Karnik, R. Carbon nanotube membranes with ultrahigh specific adsorption capacity for water desalination and purification. Nat. Commun. 2013, 4, 1-8. [CrossRef]

12. Zhang, C.; Zhang, R.Z.; Ma, Y.Q.; Guan, W.B.; Wu, X.L.; Liu, X.; Li, H.; Du, Y.L.; Pan, C.P. Preparation of cellulose/graphene composite and its applications for triazine pesticides adsorption from water. ACS Sustain. Chem. Eng. 2015, 3, 396-405. [CrossRef]

13. Crini, G.; Saintemarie, A.E.; Rocchi, S.; Fourmentin, M.; Jeanvoine, A.; Millon, L.; Morin-Crini, N. Simultaneous removal of five triazole fungicides from synthetic solutions on activated carbons and cyclodextrin-based adsorbents. Heliyon 2017, 3, e00380. [CrossRef]

14. Saleh, I.A.; Zouari, N.; Al-Ghouti, M.A. Removal of pesticides from water and wastewater: Chemical, physical and biological treatment approaches. Environ. Technol. Innov. 2020, 19, 101026. [CrossRef]

15. Suo, F.; Liu, X.; Li, C.; Yuan, M.; Zhang, B.; Wang, J.; Ma, Y.; Lai, Z.; Ji, M. Mesoporous activated carbon from starch for superior rapid pesticides removal. Int. J. Biol. Macromol. 2019, 121, 806-813. [CrossRef]

16. Ma, G.; Zhang, M.; Zhu, L.; Chen, H.; Liu, X.; Lu, C. Facile synthesis of amine-functional reduced graphene oxides as modified quick, easy, cheap, effective, rugged and safe adsorbent for multi-pesticide residues analysis of tea. J. Chromatogr. A 2018, 1531, 22-31. [CrossRef]

17. Nazir, M.S.; Tahir, Z.; Hassan, S.U.; Ali, Z.; Akhtar, M.N.; Azam, K.; Abdullah, M.A. Remediation of Pesticide in Water. In Sustainable Agriculture Reviews 47; Springer: Berlin/Heidelberg, Germany, 2021; pp. 271-307.

18. Zhang, Z.; Jiang, W.; Jian, Q.; Song, W.; Zheng, Z.; Wang, D.; Liu, X. Residues and dissipation kinetics of triazole fungicides difenoconazole and propiconazole in wheat and soil in Chinese fields. Food Chem. 2015, 168, 396-403. [CrossRef]

19. Wang, Z.H.; Yang, T.; Qin, D.M.; Gong, Y.; Ji, Y. Determination and dynamics of difenoconazole residues in Chinese cabbage and soil. Chin. Chem. Lett. 2008, 19, 969-972. [CrossRef]

20. Dong, F.; Li, J.; Chankvetadze, B.; Cheng, Y.; Xu, J.; Liu, X.; Li, Y.; Chen, X.; Bertucci, C.; Tedesco, D. Chiral triazole fungicide difenoconazole: Absolute stereochemistry, stereoselective bioactivity, aquatic toxicity, and environmental behavior in vegetables and soil. Environ. Sci. Technol. 2013, 47, 3386-3394. [CrossRef] [PubMed]

21. Azbar, N.; Bayram, A.; Filibeli, A.; Muezzinoglu, A.; Sengul, F.; Ozer, A. A review of waste management options in olive oil production. Crit. Rev. Environ. Sci. Technol. 2004, 34, 209-247. [CrossRef]

22. Hamed, O.A.; Foad, Y.; Hamed, E.M.; Al-Hajj, N. Cellulose powder from olive industry solid waste. BioResources 2012, 7, 4190-4201.

23. Salameh, Y.F.A.H. Methods of Extracting Cellulosic Material From Olive Pulp. Master's Thesis, An-Najah National University, Nablus, Palestine, 2009.

24. Ayrilmis, N.; Buyuksari, U. Utilization of olive mill sludge in the manufacture of fiberboard. BioResources 2010, 5, $1859-1867$.

25. Ramos, L.A.; Morgado, D.L.; Gessner, F.; Frollini, E.; El Seoud, O.A. A physical organic chemistry approach to dissolution of cellulose: Effects of cellulose mercerization on its properties and on the kinetics of its decrystallization. Arkivoc 2011, 7, 416-425. [CrossRef]

26. Medronho, B.; Lindman, B. Competing forces during cellulose dissolution: From solvents to mechanisms. Curr. Opin. Colloid Interface Sci. 2014, 19, 32-40. [CrossRef]

27. Balamurugan, R.; Sundarrajan, S.; Ramakrishna, S. Recent trends in nanofibrous membranes and their suitability for air and water filtrations. Membranes 2011, 1, 232-248. [CrossRef] [PubMed]

28. Banasiak, L.J.; Van der Bruggen, B.; Schäfer, A.I. Sorption of pesticide endosulfan by electrodialysis membranes. Chem. Eng. J. 2011, 166, 233-239. [CrossRef]

29. Thaçi, V.; Hoti, R.; Berisha, A.; Bogdanov, J. Corrosion study of copper in aqueous sulfuric acid solution in the presence of (2E, 5E)-2, 5-dibenzylidenecyclopentanone and (2E, 5E)-bis [(4-dimethylamino) benzylidene] cyclopentanone: Experimental and theoretical study. Open Chem. 2020, 18, 1412-1420. [CrossRef]

30. Khalaf, B.; Hamed, O.; Jodeh, S.; Hanbali, G.; Bol, R.; Dagdag, O.; Samhan, S. Novel, Environment-Friendly Cellulose-Based Derivatives for Tetraconazole Removal from Aqueous Solution. Polymers 2021, 13, 450. [CrossRef]

31. Kowsaka, K.; Okajima, K.; Kamide, K. Two-dimensional nuclear magnetic resonance spectra of cellulose and cellulose triacetate. Polym. J. 1988, 20, 1091-1099. [CrossRef]

32. Isogai, A. NMR analysis of cellulose dissolved in aqueous $\mathrm{NaOH}$ solutions. Cellulose 1997, 4, 99-107. [CrossRef]

33. Sahmoune, M.N.; Louhab, K.; Boukhiar, A. Advanced biosorbents materials for removal of chromium from water and wastewaters. Environ. Prog. Sustain. Energy 2011, 30, 284-293. [CrossRef]

34. Abdel-Ghani, N.; Hefny, M.; El-Chaghaby, G.A. Removal of lead from aqueous solution using low cost abundantly available adsorbents. Int. J. Environ. Sci. Technol. 2007, 4, 67-73. [CrossRef]

35. Foo, K.Y.; Hameed, B.H. Insights into the modeling of adsorption isotherm systems. Chem. Eng. J. 2010, 156, 2-10. [CrossRef] 
36. Liu, J.N.; Chen, Z.R.; Yuan, S.F. Study on the prediction of visible absorption maxima of azobenzene compounds. J. Zhejiang Univiversity. Sci. B 2005, 6, 584. [CrossRef]

37. Adejo, S.O. Proposing a new empirical adsorption isotherm known as Adejo-Ekwenchi isotherm. J. Appl. Chem. 2014, 6, 66-71. [CrossRef]

38. He, J.; Hong, S.; Zhang, L.; Gan, F.; Ho, Y.-S. Equilibrium and thermodynamic parameters of adsorption of methylene blue onto rectorite. Fresenius Environ. Bull. 2010, 19, 2651-2656.

39. Sridev, D.; Rajendran, K. Synthesis and optical characteristics of ZnO nanocrystals. Bull. Mater. Sci. 2009, 32, 165-168. [CrossRef]

40. Ferrari, L.; Kaufmann, J.; Winnefeld, F.; Plank, J. Interaction of cement model systems with superplasticizers investigated by atomic force microscopy, zeta potential, and adsorption measurements. J. Colloid Interface Sci. 2010, 347, 15-24. [CrossRef]

41. Vecitis, C.D.; Park, H.; Cheng, J.; Mader, B.T.; Hoffmann, M.R. Treatment technologies for aqueous perfluorooctanesulfonate (PFOS) and perfluorooctanoate (PFOA). Front. Environ. Sci. Eng. China 2009, 3, 129-151. [CrossRef]

42. Agrawal, A.; Sahu, K. Kinetic and isotherm studies of cadmium adsorption on manganese nodule residue. J. Hazard. Mater. 2006, 137, 915-924. [CrossRef]

43. Lin, J.; Wang, L. Comparison between linear and non-linear forms of pseudo-first-order and pseudo-second-order adsorption kinetic models for the removal of methylene blue by activated carbon. Front. Environ. Sci. Eng. China 2009, 3, 320-324. [CrossRef]

44. Li, Y.-H.; Wang, S.; Luan, Z.; Ding, J.; Xu, C.; Wu, D. Adsorption of cadmium (II) from aqueous solution by surface oxidized carbon nanotubes. Carbon 2003, 41, 1057-1062. [CrossRef]

45. Uğurlu, M.; Gürses, A.; Açıkyıldız, M. Comparison of textile dyeing effluent adsorption on commercial activated carbon and activated carbon prepared from olive stone by $\mathrm{ZnCl} 2$ activation. Microporous Mesoporous Mater. 2008, 111, 228-235. [CrossRef]

46. Tan, I.; Hameed, B.; Ahmad, A. Equilibrium and kinetic studies on basic dye adsorption by oil palm fibre activated carbon. Chem. Eng. J. 2007, 127, 111-119. [CrossRef]

47. Hamed, O.; Lail, B.A.; Deghles, A.; Qasem, B.; Azzaoui, K.; Obied, A.A.; Algarra, M.; Jodeh, S. Synthesis of a cross-linked cellulose-based amine polymer and its application in wastewater purification. Environ. Sci. Pollut. Res. 2019, 26, 28080-28091. [CrossRef]

48. Hanbali, G.; Jodeh, S.; Hamed, O.; Bol, R.; Khalaf, B.; Qdemat, A.; Samhan, S. Enhanced Ibuprofen Adsorption and Desorption on Synthesized Functionalized Magnetic Multiwall Carbon Nanotubes from Aqueous Solution. Materials 2020, 13, 3329. [CrossRef]

49. Striegel, A.M. Advances in the understanding of the dissolution mechanism of cellulose in DMAc/LiCl. J. Chil. Chem. Soc. 2003, 48, 73-77. [CrossRef]

50. Hsissou, R.; Benhiba, F.; Abbout, S.; Dagdag, O.; Benkhaya, S.; Berisha, A.; Erramli, H.; Elharfi, A. Trifunctional epoxy polymer as corrosion inhibition material for carbon steel in $1.0 \mathrm{M} \mathrm{HCl}$ : MD simulations, DFT and complexation computations. Inorg. Chem. Commun. 2020, 115, 107858. [CrossRef]

51. Hsissou, R.; Abbout, S.; Seghiri, R.; Rehioui, M.; Berisha, A.; Erramli, H.; Assouag, M.; Elharfi, A. Evaluation of corrosion inhibition performance of phosphorus polymer for carbon steel in [1 M] HCl: Computational studies (DFT, MC and MD simulations). J. Mater. Res. Technol. 2020, 9, 2691-2703. [CrossRef]

52. Hsissou, R.; Dagdag, O.; Abbout, S.; Benhiba, F.; Berradi, M.; El Bouchti, M.; Berisha, A.; Hajjaji, N.; Elharfi, A. Novel derivative epoxy resin TGETET as a corrosion inhibition of E24 carbon steel in $1.0 \mathrm{M} \mathrm{HCl}$ solution. Experimental and computational (DFT and MD simulations) methods. J. Mol. Liq. 2019, 284, 182-192. [CrossRef]

53. Dagdag, O.; Berisha, A.; Safi, Z.; Hamed, O.; Jodeh, S.; Verma, C.; Ebenso, E.E.; El Harfi, A. DGEBA-polyaminoamide as effective anti-corrosive material for $15 \mathrm{CDV} 6$ steel in $\mathrm{NaCl}$ medium: Computational and experimental studies. J. Appl. Polym. Sci. 2020, 137. [CrossRef]

54. Dagdag, O.; Hsissou, R.; El Harfi, A.; Berisha, A.; Safi, Z.; Verma, C.; Ebenso, E.; Touhami, M.E.; El Gouri, M. Fabrication of polymer based epoxy resin as effective anti-corrosive coating for steel: Computational modeling reinforced experimental studies. Surf. Interfaces 2020, 18, 100454. [CrossRef]

55. Sun, H.; Jin, Z.; Yang, C.; Akkermans, R.L.; Robertson, S.H.; Spenley, N.A.; Miller, S.; Todd, S.M. COMPASS II: Extended coverage for polymer and drug-like molecule databases. J. Mol. Modeling 2016, 22, 47. [CrossRef] [PubMed]

56. El Faydy, M.; Benhiba, F.; Berisha, A.; Kerroum, Y.; Jama, C.; Lakhrissi, B.; Guenbour, A.; Warad, I.; Zarrouk, A. An experimentalcoupled empirical investigation on the corrosion inhibitory action of 7-alkyl-8-Hydroxyquinolines on C35E steel in HCl electrolyte. J. Mol. Liq. 2020, 317, 113973. [CrossRef]

57. Berisha, A. Experimental, Monte Carlo and molecular dynamic study on corrosion inhibition of mild steel by pyridine derivatives in aqueous perchloric acid. Electrochem 2020, 1, 188-199. [CrossRef]

58. Dagdag, O.; Hsissou, R.; Berisha, A.; Erramli, H.; Hamed, O.; Jodeh, S.; El Harfi, A. Polymeric-based epoxy cured with a polyaminoamide as an anticorrosive coating for aluminum 2024-T3 surface: Experimental studies supported by computational modeling. J. Bio Tribo Corros. 2019, 5, 1-13. [CrossRef]

59. Dagdag, O.; Hsissou, R.; El Harfi, A.; Safi, Z.; Berisha, A.; Verma, C.; Ebenso, E.E.; Quraishi, M.; Wazzan, N.; Jodeh, S. Epoxy resins and their zinc composites as novel anti-corrosive materials for copper in $3 \%$ sodium chloride solution: Experimental and computational studies. J. Mol. Liq. 2020, 315, 113757. [CrossRef] 